\title{
POVERTY REDUCTION AND DEVELOPMENT
}

NATIONAL STRATEGIES AND A CASE STUDY OF ADB-FUNDED PILOT PROJECT IN NAYONG COUNTY IN GUIZHOU PROVINCE, PEOPLE'S REPUBLIC OF CHINA

Nogendra Sapkota, Sangui Wang, and Guobao Wu

NO. 10

ADB EAST ASIA 
East Asia Working Paper Series

\section{Poverty Reduction and Development: National Strategies and a Case Study of ADB-Funded Pilot Project in Nayong County in Guizhou Province, People's Republic of China}

Nogendra Sapkota, Sangui Wang, and Guobao Wu

No. 10 | November 2017 
(C) 2017 Asian Development Bank 6 ADB Avenue, Mandaluyong City, 1550 Metro Manila, Philippines

Tel +632632 4444; Fax +6326362444

www.adb.org

Some rights reserved. Published in 2017.

Publication Stock No. WPS179131-2

DOI: http://dx.doi.org/10.22617/WPS179131-2

The views expressed in this publication are those of the authors and do not necessarily reflect the views and policies of the Asian Development Bank (ADB) or its Board of Governors or the governments they represent.

ADB does not guarantee the accuracy of the data included in this publication and accepts no responsibility for any consequence of their use. The mention of specific companies or products of manufacturers does not imply that they are endorsed or recommended by ADB in preference to others of a similar nature that are not mentioned.

By making any designation of or reference to a particular territory or geographic area, or by using the term "country" in this document, $A D B$ does not intend to make any judgments as to the legal or other status of any territory or area.

This work is available under the Creative Commons Attribution 3.0 IGO license (CC BY 3.0 IGO) https://creativecommons.org/licenses/by/3.0/igo/. By using the content of this publication, you agree to be bound by the terms of this license. For attribution, translations, adaptations, and permissions, please read the provisions and terms of use at https://www.adb.org/terms-use\#openaccess

This CC license does not apply to non-ADB copyright materials in this publication. If the material is attributed to another source, please contact the copyright owner or publisher of that source for permission to reproduce it.

ADB cannot be held liable for any claims that arise as a result of your use of the material.

Please contact pubsmarketing@adb.org if you have questions or comments with respect to content, or if you wish to obtain copyright permission for your intended use that does not fall within these terms, or for permission to use the ADB logo.

Note: ADB recognizes “China” as the People's Republic of China.

Corrigenda to ADB publications may be found at http://www.adb.org/publications/corrigenda

The ADB East Asia Working Paper Series is a forum for stimulating discussion and eliciting feedback on ongoing and recently completed research and policy studies undertaken by the East Asia Department of the Asian Development Bank (ADB) staff, consultants, or resource persons. The series deals with key economic and development problems, as well as conceptual, analytical, or methodological issues relating to project/program economic analysis, and statistical data and measurement. The series aims to enhance the knowledge on Asia's development and policy challenges; strengthen analytical rigor and quality of ADB's country partnership strategies, and its subregional and country operations; and improve the quality and availability of statistical data and development indicators for monitoring development effectiveness.

The ADB East Asia Working Paper Series is a quick-disseminating, informal publication whose titles could subsequently be revised for publication as articles in professional journals or chapters in books. The series is maintained by the East Asia Department. 


\section{CONTENTS}

ACKNOWLEDGMENTS iv

EXECUTIVE SUMMARY $\quad v$

ABBREVIATIONS vi

$\begin{array}{ll}\text { I. INTRODUCTION } & 1\end{array}$

II. NATIONAL STRATEGIES ON POVERTY REDUCTION 1
A. National Rural Reform for Agricultural Development and Poverty Reduction (1978-1985)
B. National Poverty Reduction and Development Programs (1986-1993)
C. 8-7 Poverty Reduction Plan (1994-2000)
D. Rural Poverty Alleviation and Development Program (2001-2010)
E. Precision Poverty Reduction Strategy (2011-2020)

III. CASE STUDY: POVERTY REDUCTION PILOT PROJECT IN QIANQIU VILLAGE IN NAYONG COUNTY, GUIZHOU PROVINCE

A. Background

B. Project Location and Preproject Socioeconomic Conditions

C. Pilot Project and Follow-Up Activities

D. Direct Benefits from Pilot Project and Follow-Up Activities

E. Long-Term Changes in the Village

IV. CONCLUSION AND RECOMMENDATIONS 


\section{ACKNOWLEDGMENTS}

The authors-Nogendra Sapkota, senior social development specialist, Asian Development Bank (ADB); and consultants Sangui Wang and Guobao Wu-would like to thank ADB's East Asia Department (EARD), particularly Qingfeng Zhang, director of the Environment, Natural Resources, and Agriculture Division (EAER) of EARD, for encouraging the authors to publish the paper; and Indu Bhushan, director general, EARD, for his endorsement of this publication. The authors appreciate the comments provided during the technical assistance workshops; and the reviews, clearance, and support from colleagues and management of EARD, including M. Teresa Kho, deputy director general, EARD; Robert Schoellhammer, Advisor, Office of the Director General (EAOD)/EARD; Yoshiaki Kobayashi, principal water resources specialist, EAER/EARD; Marzia Mongiorgi, principal country specialist, ADB's resident mission in the People's Republic of China (PRC Resident Mission [PRCM])/EARD; Akiko Terada-Hagiwara, principal economist, EAOD/EARD; Sophia Castillo-Plaza, associate knowledge management officer, EAOD/EARD; and Emmalou Guillarte and Joel Pinaroc, consultants, EAOD/EARD. The authors also acknowledge the support of Heidee Luna, senior project assistant, EAER/EARD; Joy Quitazol-Gonzalez, consultant, EAER/EARD; and the staff of the Department of External Relations, including Rodel Bautista, communications assistant; Ma. Katrina Fernando, communications assistant (publishing); and Cynthia Hidalgo, associate communications officer (publishing), for their help in the publication process. 


\section{EXECUTIVE SUMMARY}

Poverty reduction and development is a challenging task. It requires sound national poverty reduction strategies and good local practices. Over the past 3 decades, the People's Republic of China (PRC) has implemented several poverty reduction strategies and has lifted the majority of its population from poverty; although, it still has some pockets of poverty in rural areas, particularly in harsh and remote locations. The strategies have focused on providing poverty reduction opportunities by building and transferring assets to the poor in rural poverty-stricken areas.

The Asian Development Bank (ADB) has supported the PRC in implementing several projects that contribute to poverty reduction. This paper draws on the inception study conducted under the technical assistance to the PRC for Poverty Reduction in Liupanshan, Ningxia Hui Autonomous Region to provide a summary of the PRC's national poverty reduction strategies. The paper also highlights a case study which draws heavily on an evaluation study of a poverty reduction pilot project in Nayong County of Guizhou Province in the PRC that was funded by the ADB and conducted under the regional technical assistance for Supporting Strategic Knowledge Products and Research Networking. It shows how national poverty reduction strategies and local-level projects can contribute successfully to poverty reduction and development, and highlights the remaining challenges, particularly in harsh and remote locations. 


\section{ABBREVIATIONS}

$\begin{array}{lll}\text { ADB } & - & \text { Asian Development Bank } \\ \text { DVD } & - & \text { digital video disc } \\ \text { FFW } & - & \text { food for work } \\ \mathrm{kg} & - & \text { kilogram } \\ \mathrm{km} & - & \text { kilometer } \\ \text { LGPRD } & - & \text { Leading Group for Poverty Reduction and Development } \\ \text { NBS } & - & \text { National Bureau of Statistics } \\ \text { PRC } & - & \text { People's Republic of China }\end{array}$




\section{INTRODUCTION}

Over the past 3 decades, the majority of the population has been lifted from poverty in the People's Republic of China (PRC). However, the PRC still has a concentration of poverty in rural areas, and millions of people living in harsh and remote locations remain poor.

The PRC has defined its poverty line in terms of consumption and income of the rural population, and has implemented many national poverty reduction strategies and policies.

The Asian Development Bank (ADB) has supported the PRC in implementing several projects that contribute to poverty reduction. This paper summarizes the PRC's national poverty reduction strategies and highlights a case study of an ADB-funded pilot project in Nayong County of Guizhou Province in the PRC.

\section{NATIONAL STRATEGIES ON POVERTY REDUCTION}

The poverty reduction strategies of the PRC have emphasized the provision of opportunities by building and transferring physical and human assets to the poor in rural poverty-stricken areas. In remote and designated rural areas, poverty reduction programs have played a key role in investing in infrastructure, agricultural and non-agricultural productions, and accumulating human capital by developing rural education, health care, and culture.

The PRC's poverty reduction strategies can be categorized into five phases since the late 1970s when the PRC started its reform and opening-up policies. These include (i) the National Rural Reform for Agricultural Development and Poverty Reduction during 1978-1985, (ii) the National Poverty Reduction and Development Programs during 1986-1993, (iii) the 8-7 Poverty Reduction Plan during 1994-2000, (iv) the Rural Poverty Alleviation and Development Program during 2001-2010, and (v) the Precision Poverty Reduction Strategy during 2011-2020.

\section{A. National Rural Reform for Agricultural Development and Poverty Reduction (1978-1985)}

Poverty was widespread until the late 1970s. The most important task during this period was to boost agricultural production and rural economic growth through rural institutional and policy reforms. A wide range of institutional and policy reforms were undertaken in the early 1980s. The fundamental change was the implementation of the household responsibility system to allow individual households to decide on what and how to produce on their contracted land in rural areas. At the same time, the government increased procurement prices of agricultural products, opened the rural market, and encouraged the development of rural enterprises.

The impact of the reforms on agricultural production and poverty reduction was remarkable. Agricultural production increased annually by 6.5\% from 1978 to 1985, while per capita rural household income at constant price rose annually by $15.2 \%$ over the same period. ${ }^{\prime}$ The food shortage problem was greatly eased and nutritional status improved. Benefits were even greater in some extremely poor

\footnotetext{
Government of the PRC, National Bureau of Statistics (NBS). 2016. China Statistical Yearbook 2016. Beijing: China
} Statistics Press. 
regions where poor population is concentrated. ${ }^{2}$ Since poverty was widespread across the country and income distribution was equal, agricultural and income growth delivered universal rural poverty reduction during this period. Measured at the 1978 official poverty line set by the National Bureau of Statistics (NBS), the PRC's rural poor population dropped from 250 million in 1978 to 125 million in 1985. ${ }^{3}$

\section{B. National Poverty Reduction and Development Programs (1986-1993)}

The PRC launched its rural poverty reduction programs in the mid-1980s to promote regional development and achieve poverty reduction through targeted poverty alleviation interventions. The poverty reduction programs focused on regions with special difficulties where rural poverty was serious, particularly in the revolutionary, minority, and border regions. The State Council's Leading Group for Poverty Reduction and Development (LGPRD) was established in 1986 to coordinate poverty reduction programs. Local LGPRDs and their offices were also established at provincial, prefectural, and county levels in poor areas. A total of 332 counties were designated as national poor counties; and three main programs, i.e., subsidized loan program, food for work (FFW) program, and budgetary poor area development grants, were set up for these poor counties. The loan program provided subsidized credit to both households and enterprises for industry and agriculture in poor counties. The FFW program utilized surplus farm labor to develop infrastructure such as road, irrigation, and drinking water facilities. The government budgetary grants supported investment in poor areas, including technology extension, education, and health care. ${ }^{4}$ Certain preferential taxation treatment was also offered to poor counties.

Poverty reduction and regional development programs contributed to farmers' income and poverty reduction during this period. Measured at NBS 1978 poverty line, rural poor population dropped from 125 million in 1985 to 80 million in 1993 (footnote 3).

\section{8-7 Poverty Reduction Plan (1994-2000)}

The PRC launched the 8-7 Poverty Reduction Plan in 1994, aspiring to lift the majority of the remaining 80 million poor above the NBS 1978 poverty line by 2000. The 8-7 Poverty Reduction Plan aimed at (i) increasing per capita net income of households; (ii) assisting poor households with land improvement, increased cash crop, fruit and livestock production, as well as off-farm employment opportunities; (iii) providing most poor townships and markets with road access and electricity, and improving access to drinking water for most poor households; (iv) accomplishing universal primary and middle school education, and improving health services to prevent endemic and disability; (v) increasing the number of national poor counties to 592 and graduating better-off counties in the coastal provinces from the poor county list; and (vi) involving all government ministries and agencies, the coastal provinces and major municipalities, and other domestic and international organizations in poverty reduction. ${ }^{5}$

In implementing the 8-7 Poverty Reduction Plan, the PRC emphasized the responsibility of provincial government leaders for the efficiency and effectiveness of poverty reduction work in their

\footnotetext{
W. Sangui. 1994. Poverty Problems and Economic Development. Beijing: Rural Reading Materials Press.

Government of the PRC, Department of Household Survey, NBS. 2016. Poverty Monitoring Report of Rural China 2016. Beijing: China Statistics Press.

4 World Bank. 2001. China: Overcoming Rural Poverty. Washington, DC.

5 Leading Group for Poverty Reduction and Development (LGPRD). 1994. The 8-7 Poverty Reduction Plan. Beijing.
} 
jurisdictions. ${ }^{6}$ After the 1996 National Poverty Reduction Conference, annual funding for poverty alleviation from the central government increased by over $50 \%$ in real terms. Three funding channels launched in 1986 were maintained, i.e., subsidized loans program, FFW program, and government budgetary grants. The subsidized loans program managed by the state-owned banks accounted for the greatest increase in funding. ${ }^{7}$

Analysis reveals that the 8-7 Poverty Reduction Plan had positive impacts on the designated national poor counties in fund allocation and increase in income. Empirical evidence reveals that the funds allocation across the national poor counties under the 8-7 Poverty Reduction Plan was highly correlated with poverty incidence, i.e., the poorer counties received more funding from the central and provincial governments. ${ }^{8}$ Using the NBS 1978 poverty line, the number of rural poor reduced from 80 million in 1993 to 32 million in 2000 (footnote 3).

\section{Rural Poverty Alleviation and Development Program (2001-2010)}

The PRC formulated and launched the Rural Poverty Reduction and Development Compendium (2001-2010) in 2001. A number of important policy changes were made. One major change was the shifting from county poverty targeting to village poverty targeting, though 592 national key poor counties were still designated. The PRC updated the list of 592 key poor counties and designated 150,000 poor villages both in and out of key poor counties as the main targets for receiving poverty alleviation assistance. The key poor counties were favorably treated in agricultural tax reform and poverty fund allocation for infrastructure and social development. Human capital accumulation and social development were emphasized more, and participatory poverty alleviation approaches were promoted in poor villages.

During this period, the LGPRD promoted three major poverty alleviation approaches: (i) integrated village development plan, (ii) labor training and migration, and (iii) industrial development in key poor counties for rural poverty reduction and regional development. Participatory integrated village development plan was conducted in the 150,000 designated key poor villages, projects were identified by the villagers themselves, and detailed budgets and funding allocation were developed with the help of outside experts and local governments. ${ }^{9}$ Recognizing the importance of rural-urban migration for providing job opportunities to the poor, new policy initiatives were implemented to help young labors to migrate and find jobs in towns and cities. Local governments organized training workshops and sponsored labor migration service centers; and vocational schools helped train migrants find jobs in coastal regions and cities. The LGPRD and the Agricultural Bank of China jointly promoted industrial development, including specialized agricultural production through the development of dragon-head agricultural enterprises in poor counties. Qualified enterprises involved in agribusiness could apply for subsidized loans from local branches of the Agricultural Bank of China, and poor farming households specialized in certain kinds of agricultural production could indirectly get loans from these enterprises.

6 Accountability of local government leaders for poverty reduction performance was confirmed as the "poverty reduction responsibility system" in the 1996 National Poverty Reduction Conference.

7 The subsidized loans program was mainly financed through the banking system, with its fiscal cost visible only many years later when banks have required capital injection. This fact made it politically easier to expand the subsidized loans program, compared with the programs financed directly from the government's own budget.

8 A. Park, W. Sangui, and G. Wu. 2002. Regional Poverty Targeting in China. Journal of Public Economics. 86. pp. $123-153$.

9 H. Gao, W. Wang, and C. Huang. 2001. Study on Poverty Reduction and Development Planning. Beijing: China Financial \& Economic Publishing House; and LGPRD. 2001. China's Rural Poverty Reduction and Development Compendium (20012010). Beijing. 
It was required that at least 500 poor households should benefit from the enterprise that received the subsidized loan.

Overall, the rural poverty reduction and development programs during this period greatly enhanced the development capacity of local communities, and benefitted a large number of households through investments in infrastructure such as road and irrigation, schools, health clinics, agricultural technology training, and extension services in poor villages. Measured at the NBS 1978 poverty line, the rural poor population decreased from 32 million in 2000 to 15 million in 2007 (footnote 3).

\section{E. Precision Poverty Reduction Strategy (2011-2020)}

In 2011, the PRC launched a new Poverty Reduction Plan for 2011-2020. The poverty line was increased to CNY2,300 at 2010 constant price, and it resulted in the total number of rural poor population at 166 million. The main objectives of the new poverty reduction plan were to (i) lift all the poor population under this poverty line out of poverty by 2020, and (ii) further narrow the gaps of economic and social developments between poor and non-poor regions. The PRC designated 14 poor regions with special difficulties, 832 poor counties, and 128,000 poor villages to receive government assistance. To effectively help poor households and individuals, the PRC began to directly target poor households. In November 2013, President Xi Jinping introduced the strategy of "precision poverty alleviation." To facilitate the implementation of this strategy, the PRC formulated its 13th Five-Year Poverty Reduction Plan in 2016, with the following five key programs: ${ }^{10}$

(i) Support poor households through agricultural and industrial development as well as off-farm employment, and solve their difficulties in relation to technology, capital, and marketing. For instance, economic entities such as rural enterprises, cooperatives, and large-scale farmers are encouraged by local governments to provide technical and marketing services to the poor. In some cases, poor households even hold shares of and get dividends from those entities after they contract land and other resources with them.

(ii) Relocate 10 million of the rural poor residents living in remote areas and in harsh natural conditions to comparatively more hospitable natural villages or small towns with a view to improving the environment and living conditions for their sustainable development. The governments and state-owned banks are expected to mobilize CNY600 billion for the relocation in the current 5 -year plan period.

(iii) Help households increase income and reduce poverty through ecological compensation policies such as subsidies for those who returned their farmlands to forests or pastures to grassland. The PRC will also greatly increase interregional ecological compensation to subsidize households in areas that provide ecosystem function.

(iv) Help poor households reduce poverty through strengthening education. The measures include developing preschool education in poor villages, providing free lunch for all primary and middle school students in poor counties, and providing free high school or vocational school education and living allowances for students from designated poor families. This will not only reduce the education expenditure of poor households, but also help end intergenerational transmission of poverty.

(v) Help poor households through enhancing social security measures such as expanding the coverage and increasing subsidies of minimum living allowances, extending and reforming rural cooperative medical care system to allow the poor to have easy access to basic health services,

10 Government of the PRC, State Council. 2016. The 13th Five-Year Poverty Reduction Plan of the PRC. Beijing. http://www.gov.cn/ zhengce/content/2016-12/02/content_5142197.htm. 
and providing severe and chronic diseases medical insurance and assistance, and pension insurance.

For implementation of the poverty reduction programs, the PRC has emphasized partnerships among local governments and other stakeholders. Local governments have worked with financial institutions in providing financial services such as credits to poor households as well as enterprises and cooperatives that participate in poverty reduction programs. Governments at various levels have dispatched officials in 128,000 designated poor villages to strengthen the capacity of local communities in the implementation of relevant programs. Nongovernment organizations, academic institutions, and ordinary citizens have been mobilized to participate in monitoring of poverty reduction programs.

Poverty reduction has been tremendous since 2010. Measured at the PRC's new poverty line of CNY2,300 in 2010 constant prices, the rural poor population has been reduced from 166 million in 2010 to 43 million in 2016 with an annual reduction rate of $20 \% .{ }^{11}$

The PRC appears to be on track of achieving its goal to eliminate extreme poverty under the current poverty line by 2020 . It will contribute greatly to the fulfillment of poverty reduction as well as sustainable development globally.

\section{CASE STUDY: POVERTY REDUCTION PILOT PROJECT IN QIANQIU VILLAGE IN NAYONG COUNTY, GUIZHOU PROVINCE}

\section{A. Background}

The Asian Development Bank (ADB) supported a poverty reduction pilot project in Qianqiu, a rural village in Nayong County of Guizhou Province in the People's Republic of China (PRC).

The pilot project was funded by an ADB technical assistance grant. ${ }^{12}$

The pilot project was developed during the PRC's 8-7 Poverty Reduction Plan of 1994-2000 that aimed to intensify poverty reduction efforts, including providing poor townships and villages with road access, electricity, and drinking water.

The implementation of the pilot project also overlapped with the beginning of the PRC's Rural Poverty Alleviation and Development Programs (2001-2010) that emphasized on integrated community development based on participatory village planning for poverty reduction in targeted poor villages.

The pilot project implemented the model of poverty reduction through participatory and integrated rural infrastructure and community development in a rural village in a nationally designated poor county. This case study summarizes the findings on the pilot project based on the technical assistance completion report and evaluation studies commissioned to evaluate the pilot project's direct benefits

\footnotetext{
$"$ Footnote 3; and Government of the PRC, NBS. 2017. Statistical Communique on National Economic and Social Development in 2016. http://www.stats.gov.cn/tjsj/zxfb/201702/t20170228_1467424.html.

12 ADB. 1998. Technical Assistance to the People's Republic of China for the Study on Ways to Support Rural Poverty Reduction Projects. Manila (TA 3150-PRC). https://www.adb.org/sites/default/files/project-document/69839/tacr-prc-3150.pdf.
} 
after its completion as well as long-term changes after a decade. ${ }^{13}$ Rapid follow-up inquiries were made to update the information while preparing this paper.

\section{B. Project Location and Preproject Socioeconomic Conditions}

Guizhou Province is in the southwest region of the PRC. The province is mountainous and almost twothirds of its land area comprise the karst areas, including rocky deserts that are prone to soil erosion and drought.

The province has the lowest gross domestic product per capita in the PRC, and its poverty ratio is much higher than the national average.

Nayong County is in the northwest part of Guizhou Province and is one of the nationally designated poor counties in the PRC. It is also mountainous and prone to rocky desertification with karst formations.

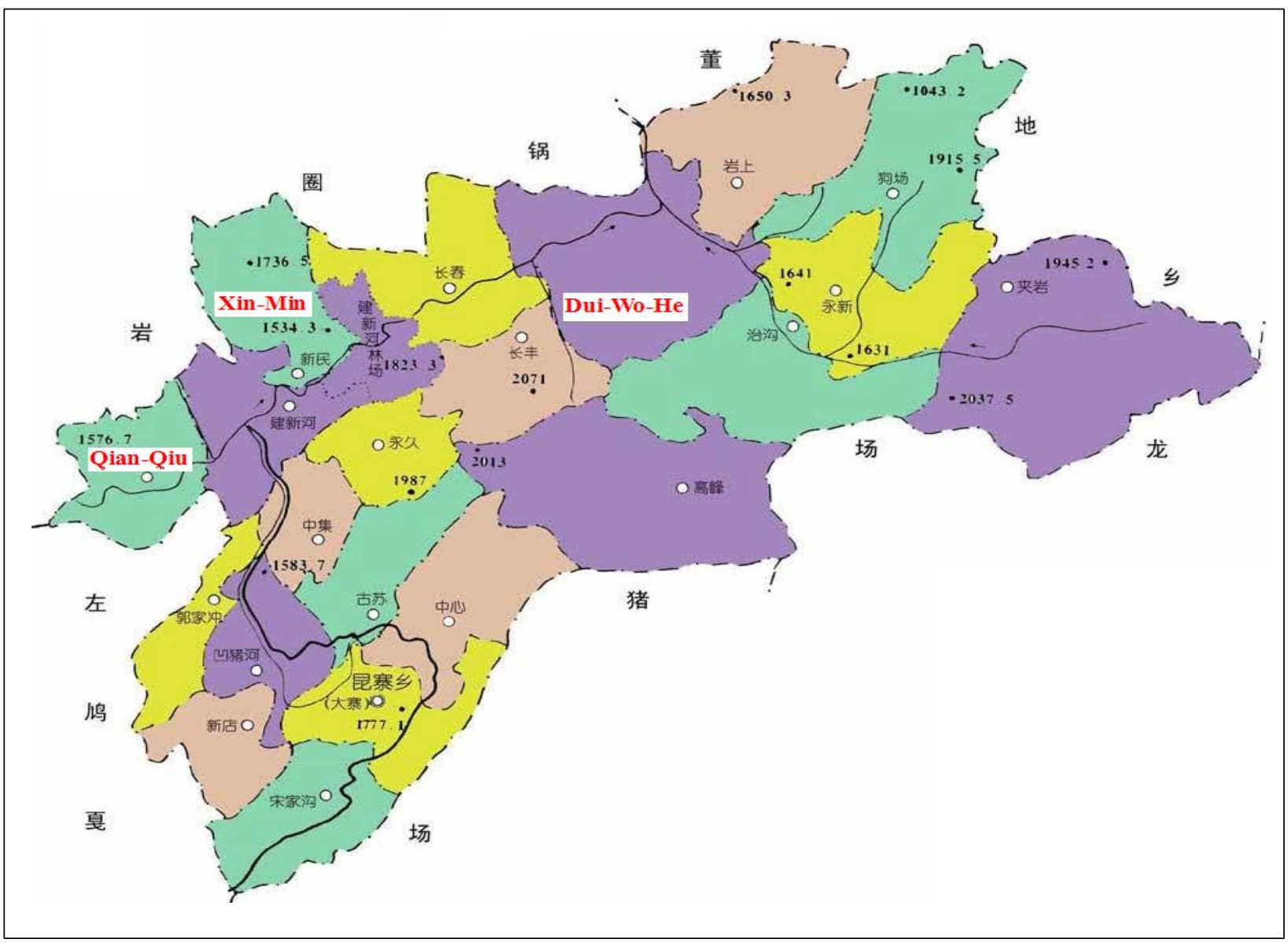

Location of Qianqiu Village in Nayong County (photo by project team).

13 ADB. 2004. Technical Assistance Completion Report: Study on Ways to Support Rural Poverty Reduction Projects in the People's Republic of China. Manila; ADB. 2012. Comprehensive Community Development for Poverty Reduction-Case Studies of Community Poverty Reduction in Nayong of Guizhou. Manila; and Center for Integrated Agriculture Development. 2012. Evaluation Report of the Pilot Project of ADB in Nayong, Guizhou Province. China Agricultural University. 
Qianqiu Village is in the southwest of Nayong County in the minority mountain area, west of Kunzhai Town. The village is 77 kilometers $(\mathrm{km})$ away from the county center and $11 \mathrm{~km}$ away from the township government station.

Jianxin River divides the village into four village groups: Anjiazhai, Lixin, Xiaoganhe, and Xiejiazhai.

Before the pilot project implementation, Qianqiu Village had 202 households; about three-fourths were Han, and the remaining were ethnic minorities (Bai, Miao, and Yi). The total population was 719; and arable land was about 1 mu per capita, with more than $90 \%$ being dryland..$^{14}$

The education level was low, and about one-third of the population was illiterate or semiliterate. Most households had 3-5 family members. The household income mainly came from farming (80\%) and labor (20\%).

More than two-thirds of the households had outstanding loans mostly borrowed from relatives and friends and which were mainly used for production and living expenses.

Corn and rice were the main food sources (about 80\%). All households owned houses, and some owned a second house as well. None of the households had television (TV) sets, digital video disc (DVD) players, washing machines, telephones, and bicycles. Only a few households had radios.

Per capita living expenditure was low, and food consumption accounted nearly three-fourths of the amount. The village was impoverished without access to a reliable drinking water supply, electricity, and all-weather roads. Health and education services were available in nearby towns. However, the quality of teaching and education was considered poor.

\section{Pilot Project and Follow-Up Activities}

The pilot project adopted the approach of integrated rural infrastructure and community development based on local participation. It comprised the following components: (i) provision of infrastructure, including drinking water, irrigation, village roads, electricity, and flood control; (ii) community development fund for microfinance; and (iii) capability building of households and the community.

Most infrastructure components of the pilot project were implemented during 2000-2002. These included (i) construction of six tap water facilities to provide water for all households in Qianqiu, except nine households living on Majiabanpo where a cement pool was constructed for these households; (ii) construction of a $2.4 \mathrm{~km}$ irrigation canal to irrigate $300 \mathrm{mu}$ paddy field; (iii) construction of a $3.8 \mathrm{~km}$ village road that was previously without pavement; and (iv) construction of an electricity grid to provide power to all households.

During 2003-2004, the project carried out the restoration of infrastructure destroyed by a flood in 2002. A bridge connecting Anjiazhai and Xiejiazhai village groups and the cement curb for the village roads were also constructed during this time.

The community development fund component distributed microfinance loans to 33 households. The community capacity building component carried out 9 practical trainings, 13 on-site instructions, and 2 excursions for village representatives.

${ }^{14} \mathrm{~A} m u$ is a Chinese unit of land measurement ( $1 \mathrm{mu}=0.067$ hectare). 
The pilot project was supervised by a group of county leaders. A project management office was set up for project implementation. Village cadres assumed the day-to-day responsibility of local participation.

ADB provided consultants and technical experts to help in project implementation, monitoring, and evaluation.

A set of follow-up interventions has been implemented in Qianqiu Village after the completion of the pilot project with support from the government. The first intervention was to further improve the infrastructure in the village. The main roads through the village were widened and a new bridge was built to link the village more closely with the county highway in the village entrance. The riverbank has been consolidated to better control the effects of flood in the river in summer. The other intervention was to support the rebuilding of houses of farmers with the housing subsidies provided by the government, which facilitated the improvement of housing conditions and more concentration of housing along the road and particularly in the village center.

\section{Direct Benefits from Pilot Project and Follow-Up Activities}

The infrastructure and other components implemented under the pilot project and follow-up activities provided several direct benefits for Qianqiu Village. The village made comprehensive progress in terms of improved road, drinking water, irrigation, power supply, housing, capacity building, and financial services. The project's direct benefits for the village after the project implementation are:

\section{Improved Drinking Water Supply}

The problem of availability and quality of drinking water was resolved. Before the project, shallow wells accounted for $80 \%$ of the total drinking water source. Under the project, Qianqiu Village established six drinking water supply facilities to improve access and the quality of drinking water. In 2016, the local government extended tap water to Miao minority households that are in the highest location of the village.

This has resulted to all households of Qianqiu Village having access to tap water. This has greatly reduced the villagers' time and labor needed in fetching water.

In addition, the use of tap water has many other benefits such as prevention of waterborne diseases, improved health and sanitation, and a better quality of life.

\section{Improved Irrigation and Flood Control}

Irrigation and food control were improved under the project, and irrigated area increased in a short term. Under the pilot project, Qianqiu Village built $2.4 \mathrm{~km}$ of irrigation canals; and three village groups got stable sources of water for irrigation.

Maintenance of the irrigation canals was contracted to villagers benefiting from the project. The irrigation canals operated well immediately after the project completion.

Before the project, problems of fluvial deposition and shrinking of irrigation canals were serious; and the flood diversion capacity of the rivers was rather weak. After the project intervention, irrigated areas increased, the flood diversion and irrigation capacity of rivers were enhanced, and the water storage capacity was boosted. 


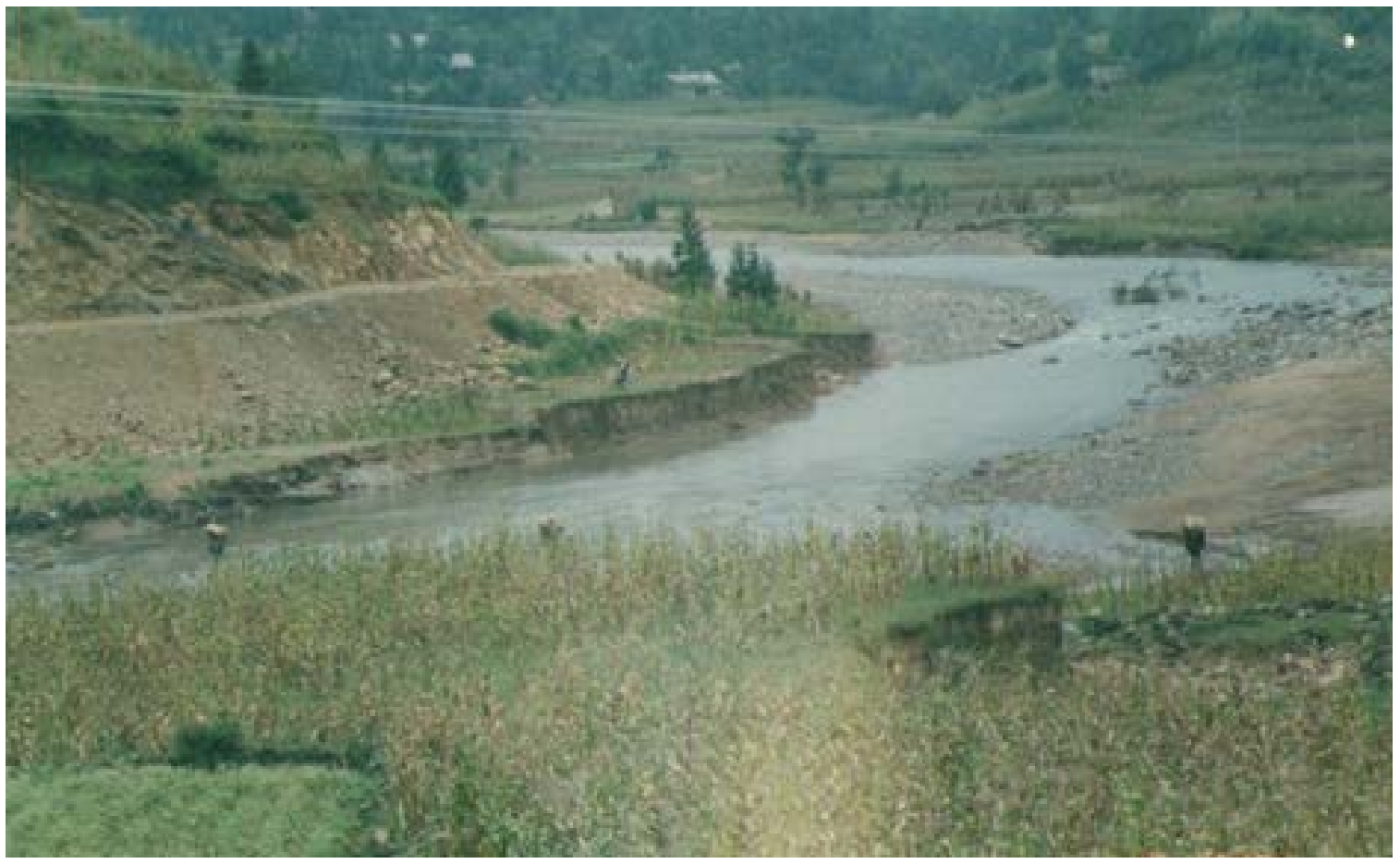

The watercourse in the village before project implementation (photo by project team).

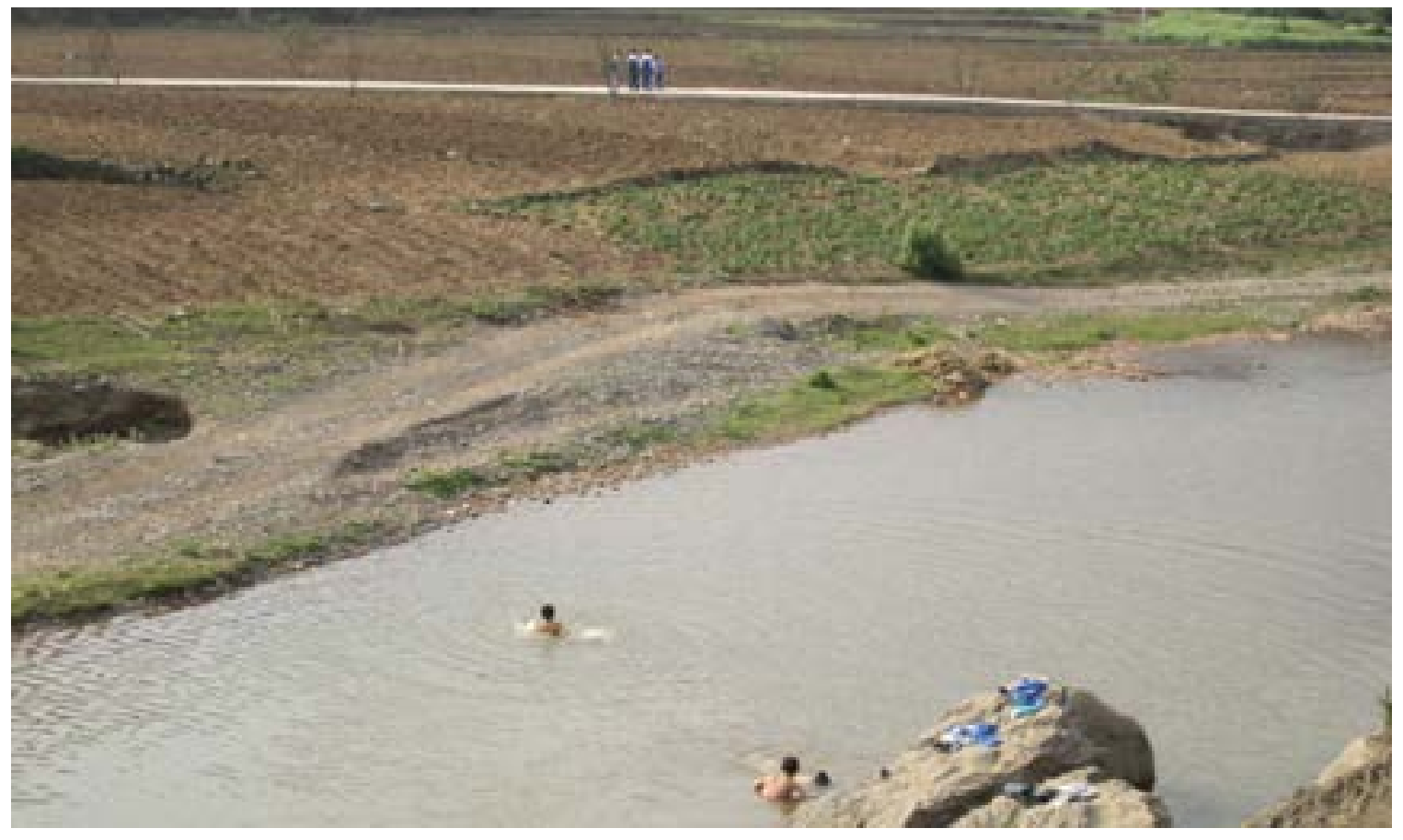

The watercourse in the village after project implementation (photo by project team). 
According to the survey after the completion of the pilot project, Qianqiu Village's per capita irrigated area increased by $52.9 \%$. The irrigated area of the households accounted for $23.8 \%$ of the total arable land area, six percentage points above the proportion before project implementation (17.8\%). However, there is currently very little water in the irrigation canals because of the drought in 2010. According to villagers, the quantity of water in the irrigation canals in 2010 was just one-tenth of that in 2003. Due to the continuous dry climate since 2010, the river has shrunk greatly, and some of the villagers engaged in the reclamation of the riverbed. Much of the paddy field on the slope of the hill and beside the river has been transformed into dryland. There has not been any change in the situation of water availability since 2010 . The water insecurity situation continues.

\section{Electricity Supply and Use}

The problem of power supply was fully solved. Under the pilot project, the village was connected with a new electricity grid to supply electricity to all households. It is considered one of the most important infrastructure, since rural electrification plays an important role in improving farmers' production efficiency as well as quality of life.

The village upgraded the electricity distribution grid and supply facilities. The facilities were managed and maintained by the local power company. The power supply was stable, and the power consumption of local residents increased. In addition, the village installed a more powerful transformer to meet the increasing electricity demand of the villagers.

The villagers used the electricity for household consumption and many other uses. Farmers bought TV sets, washing machines, refrigerators, electric motorcycles, and other electric products for household use.

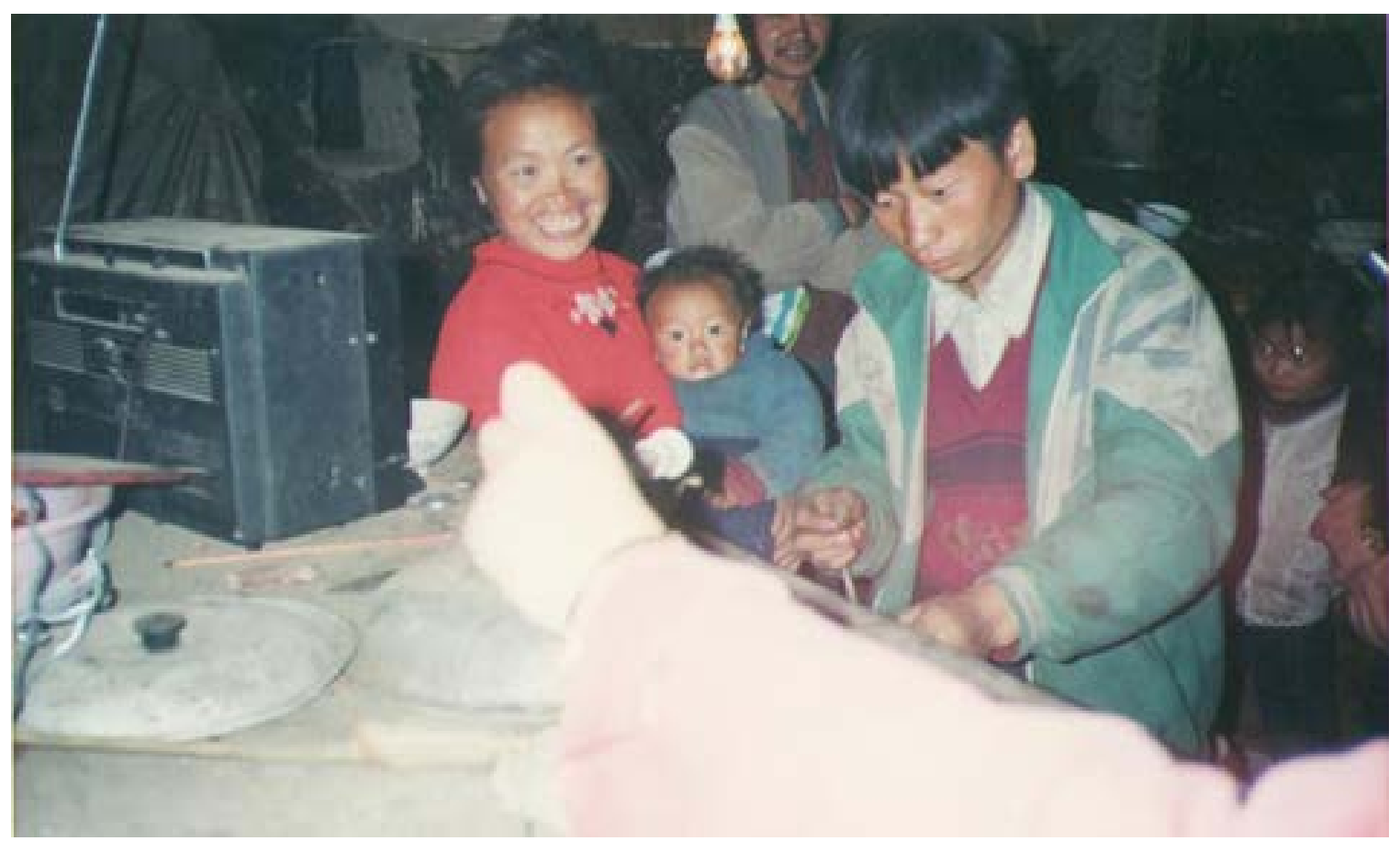

A household which did not have power supply before the project (photo by project team). 


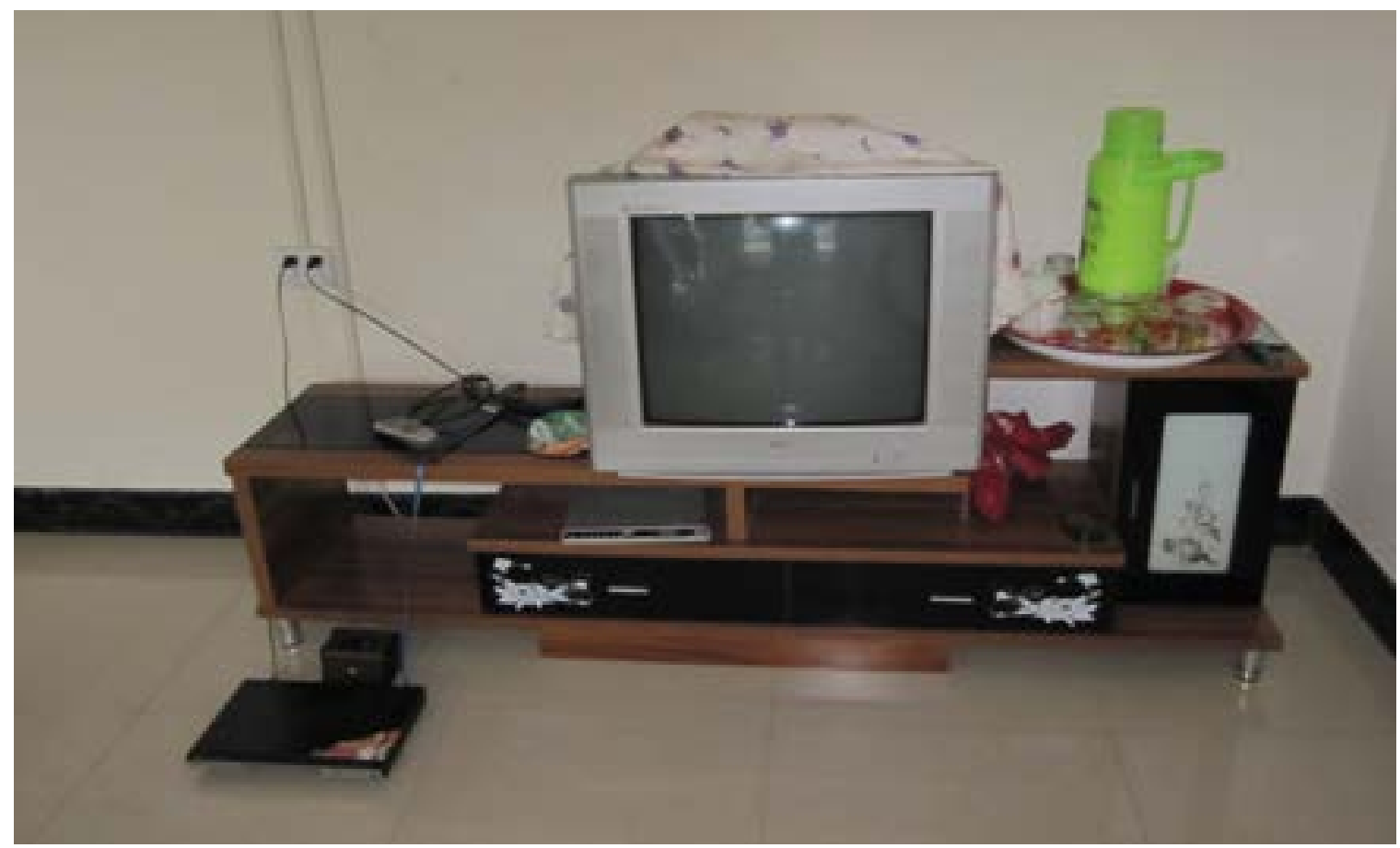

Appliances in a household which had electricity after the project implementation (photo by project team).

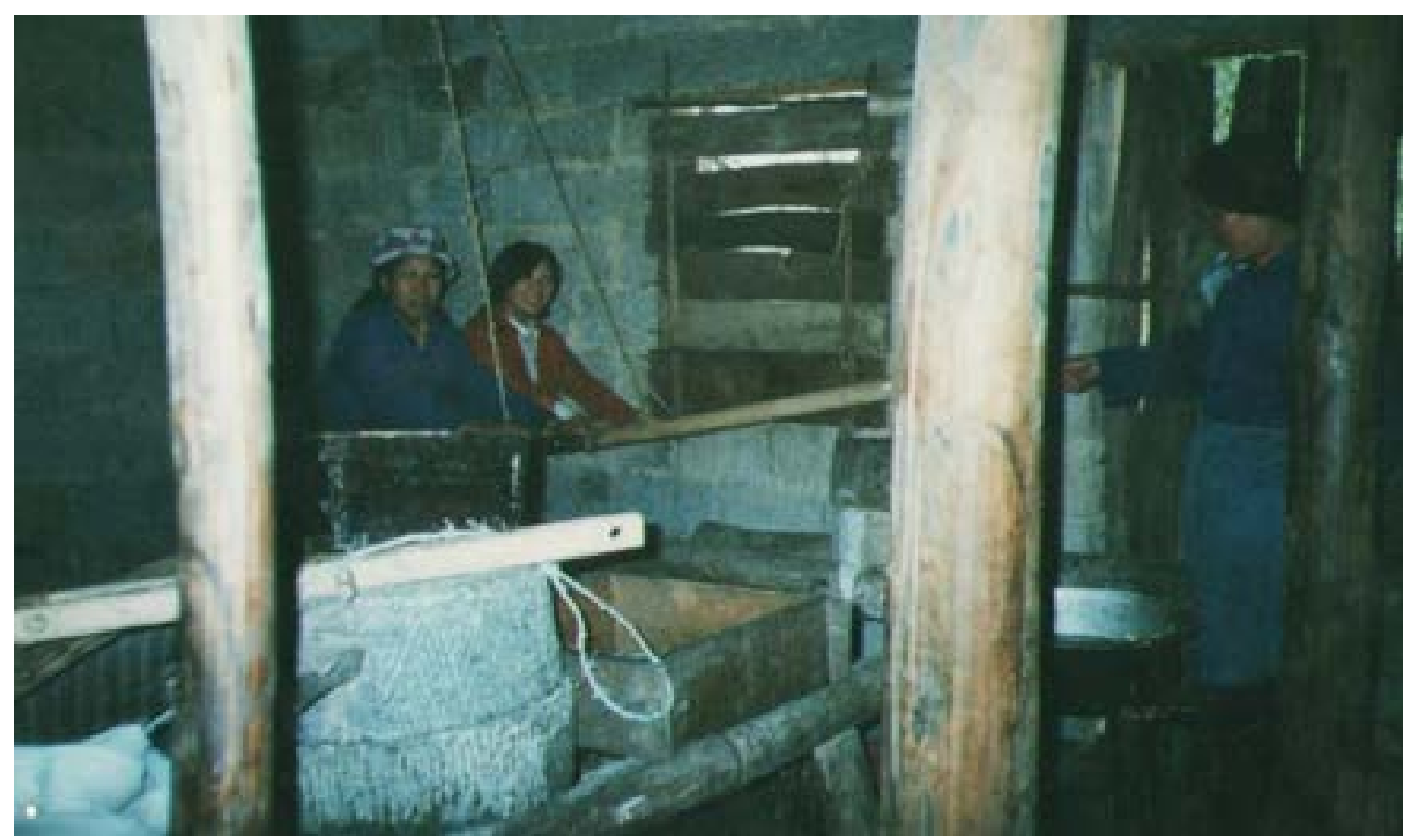

Before getting access to electricity, farmers made tofu manually with their bare hands (photo by project team).

Electricity replaced manual labor; and it is used to operate agricultural and rural industrial machines, including two small steel mills, three food-processing machines, and three sanding machines which were purchased by the villagers. 
The electricity grid in the village has been upgraded in 2016 to ensure more reliable power supply for production and living in the village. This was supported by the national plan for rural electricity upgrading.

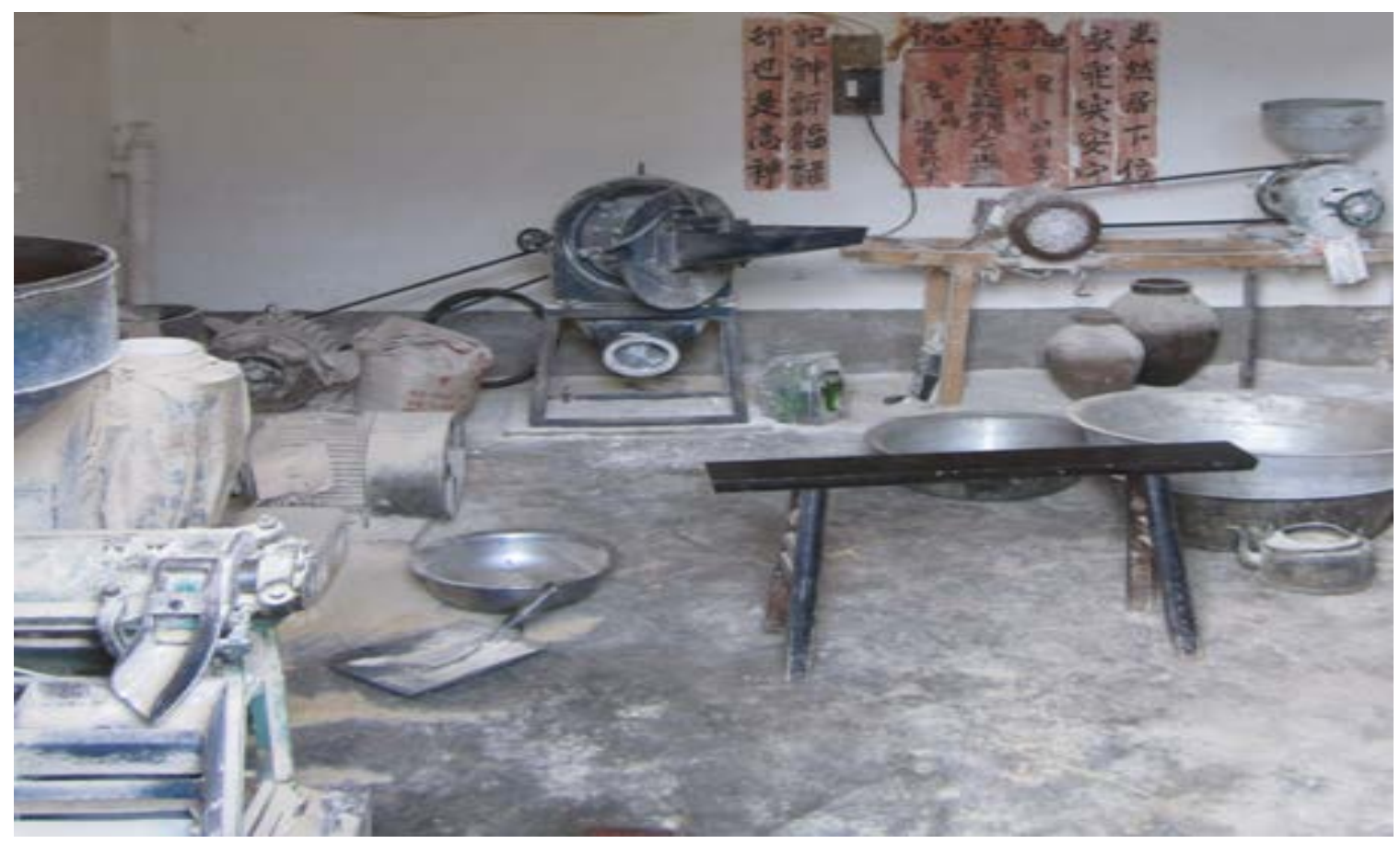

An electric-powered farmer's mill (photo by project team).

\section{Improved Rural Road and Connectivity}

Remarkable achievements were made in rural road improvement and connectivity.

The project built $3.8 \mathrm{~km}$ village roads to connect village groups with the road network. These village roads were built with high-quality pavement, and construction materials were sourced locally.

Although the roads were partly damaged by floods immediately after their construction, they were quickly rehabilitated. The roads were further improved subsequently in terms of pavement quality as well as access for households.

The roads extended into the garden of every household in Anjiazhai and Xiejiazhai village groups. The paved road connected more than $90 \%$ of the households in Qianqiu Village, except for a few households living in Majiabanpo and Niluoba village groups.

For the management and maintenance of the newly built roads and other infrastructure, Qianqiu Village has set up an infrastructure management committee.

With a lighter traffic load, the roads needed only periodic maintenance. 


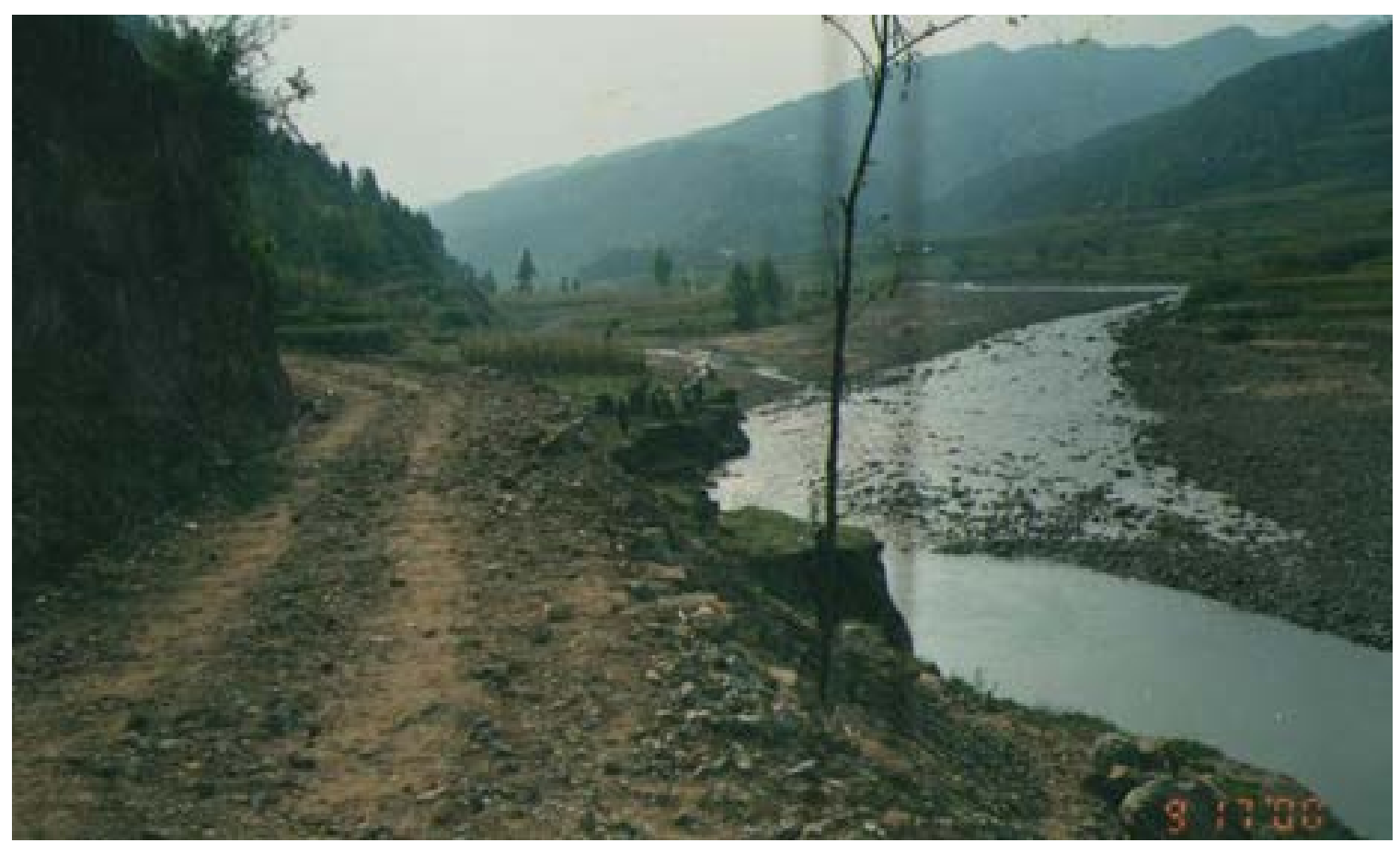

Roads in the village before the pilot project (photo by project team).

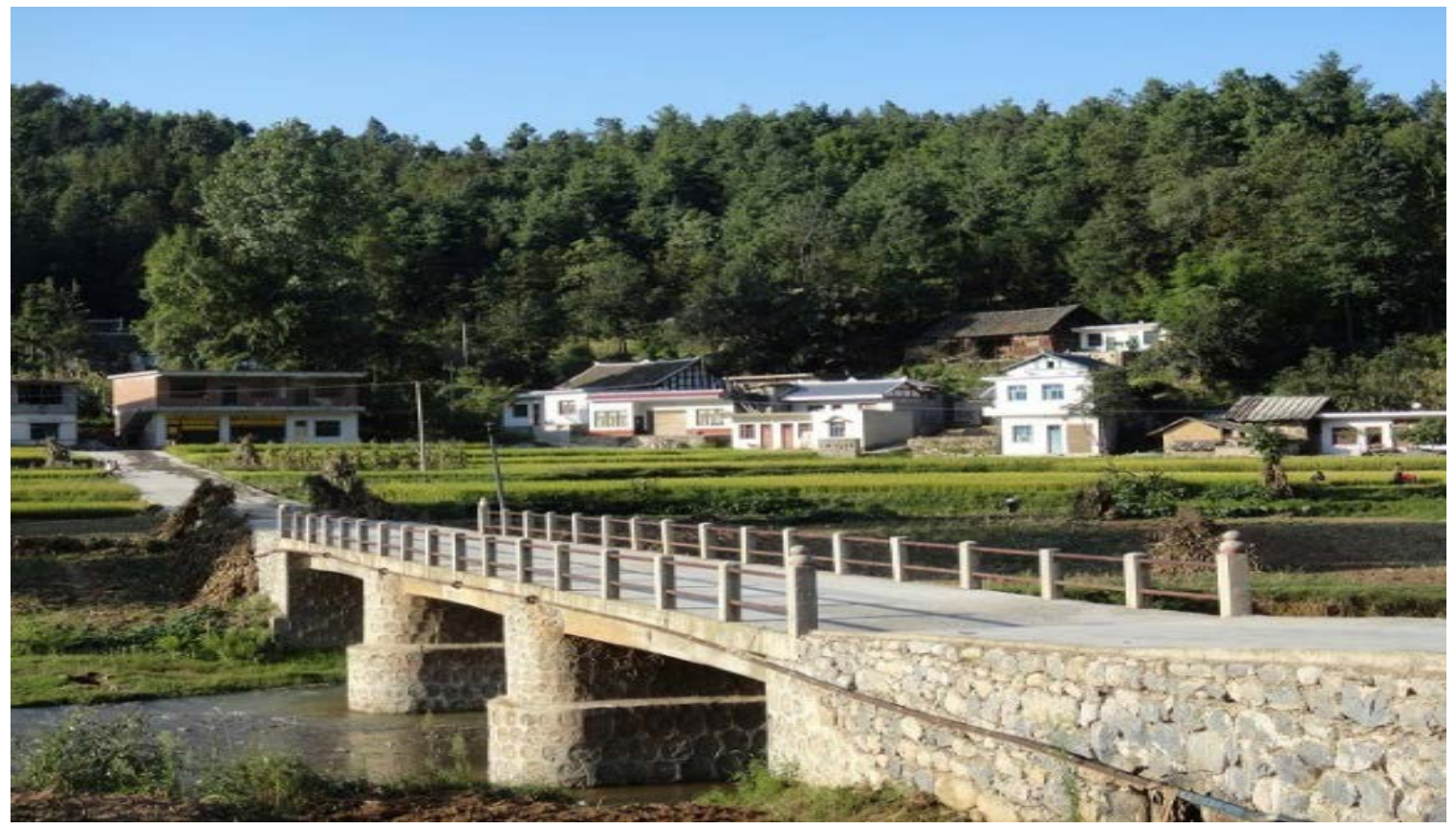

Roads in the village after the pilot project (photo by project team).

It is worth noting that the new road greatly improved the local traffic and connection with markets. It created opportunities for commercialization of agricultural and other local products. It also changed the villagers' modes of travel, improved the comfort and safety of their trips, enhanced the interconnection between the village and towns or cities, and speeded up information dissemination and exchange in rural areas. 
More households bought electric bicycles, motorcycles, and even private cars.

With the upgrading of the village road link with the county highway after the pilot project, local transportation and market connectivity are expected to further improve.

\section{Community Development Fund for Microfinance and Financial Capacity}

The provision of community development fund enhanced the accessibility of microfinance for the villagers. Before the project, the financial environment was relatively poor, restricting the development of the village.

Under the project, the community development fund provided microfinance loans to 33 rural households. Of these, 29 households used the loans for animal breeding while the other 4 used the loans to purchase vehicles. The majority of the households who obtained the loans were poor.

In addition to providing microfinance loans, the fund also built the capacity of farmers and promoted their participation in financial management. The fund organized general meetings for the villagers, which determined the relevant operation and management mechanism, loan terms, and supervision system.

Since the fund did not require farmers to present collateral, they had the flexibility to determine how to use the loan. The fund could be used for different purposes such as rural medical security, poverty alleviation, promotion of agricultural technology, and supply of goods.

There are plans to establish a government-supported community development fund for poverty alleviation to improve the credit service of villagers.

\section{Increased Awareness, Skills, and Capacity Building}

The pilot project significantly increased the awareness of new information and technology among the village leaders and residents of Qianqiu Village. They got new information by doing jobs outside their homes, and through meeting and interacting with other villagers.

Under the project, five skills trainings totaling 230 person-times were held for the village leaders and residents of Qianqiu Village. The training courses included animal husbandry and aquaculture technology, herbal medicine cultivation and winter orchard management, field technical guidance on livestock and poultries, and field visits.

The training participants from Qianqiu Village also developed the capability to organize or form social capital. The trust between the village leaders and the residents improved because of the success in terms of community organization.

The significant improvement in terms of awareness of new information and technology among the village leaders and residents of Qianqiu Village was made not just by outside interactions, but also by their access to modern media, including TV sets, mobile phones, and the internet, which were made possible due to the availability of electricity. 


\section{E. Long-Term Changes in the Village}

Qianqiu Village has witnessed significant long-term changes or indirect impacts in terms of improvements in village housing, the farmers' livelihood, and the lifestyle of the village leaders and residents.

These changes occurred beyond the pilot project, but were built on or indirectly impacted by the project initiatives. This section summarizes the changes observed after the decade of the pilot project.

\section{Changes in Village Housing}

There have been noticeable changes in Qianqiu Village's housing, including the construction of new houses and the quality of housing.

The photos show the noticeable changes in the Qianqiu Village, particularly at the village entrance. There were only two houses at the village entrance in 2001. The number of houses at the same location grew several folds, including some houses that belonged to residents from neighboring villages.

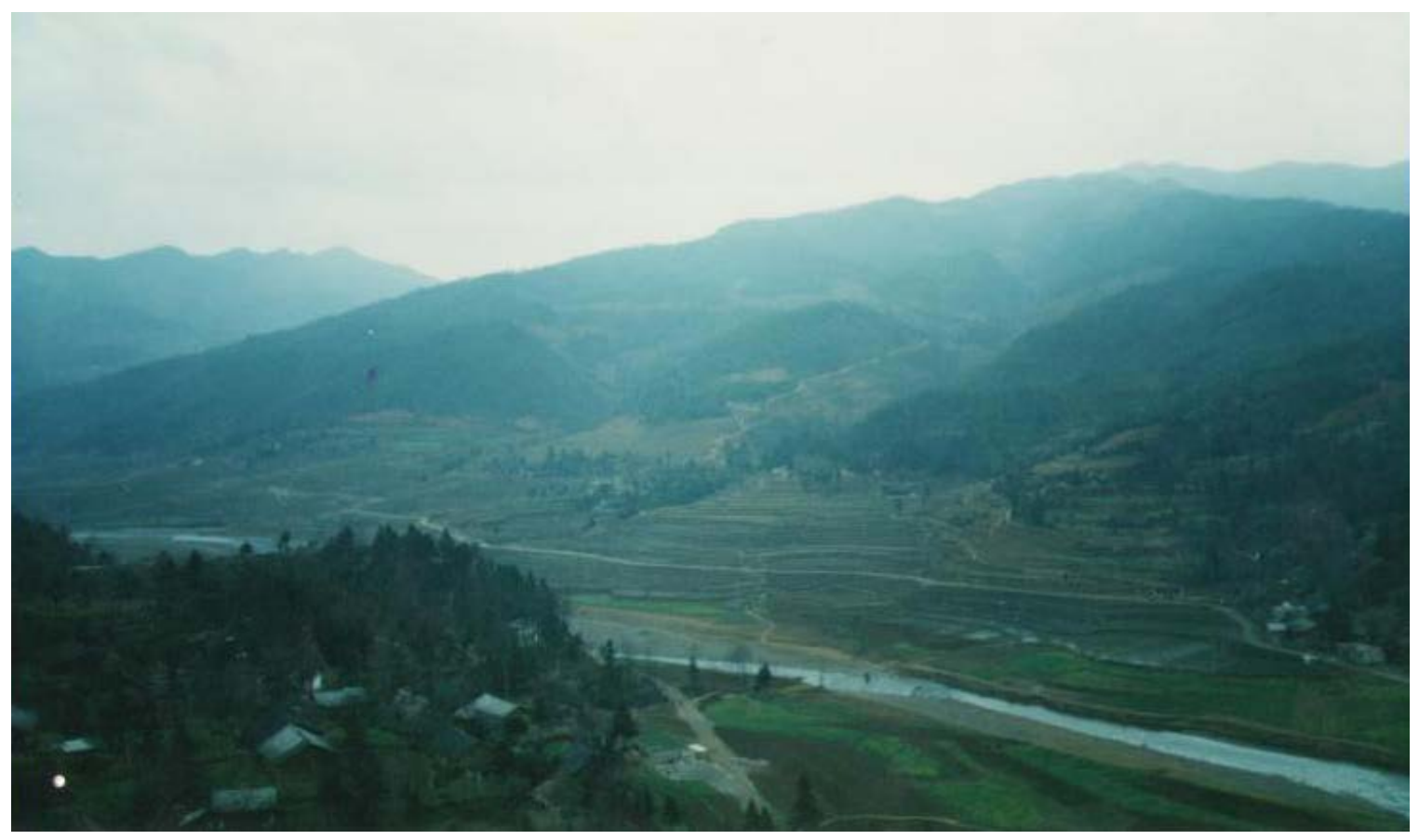

Qianqiu Village in 2001 (photo by project team). 


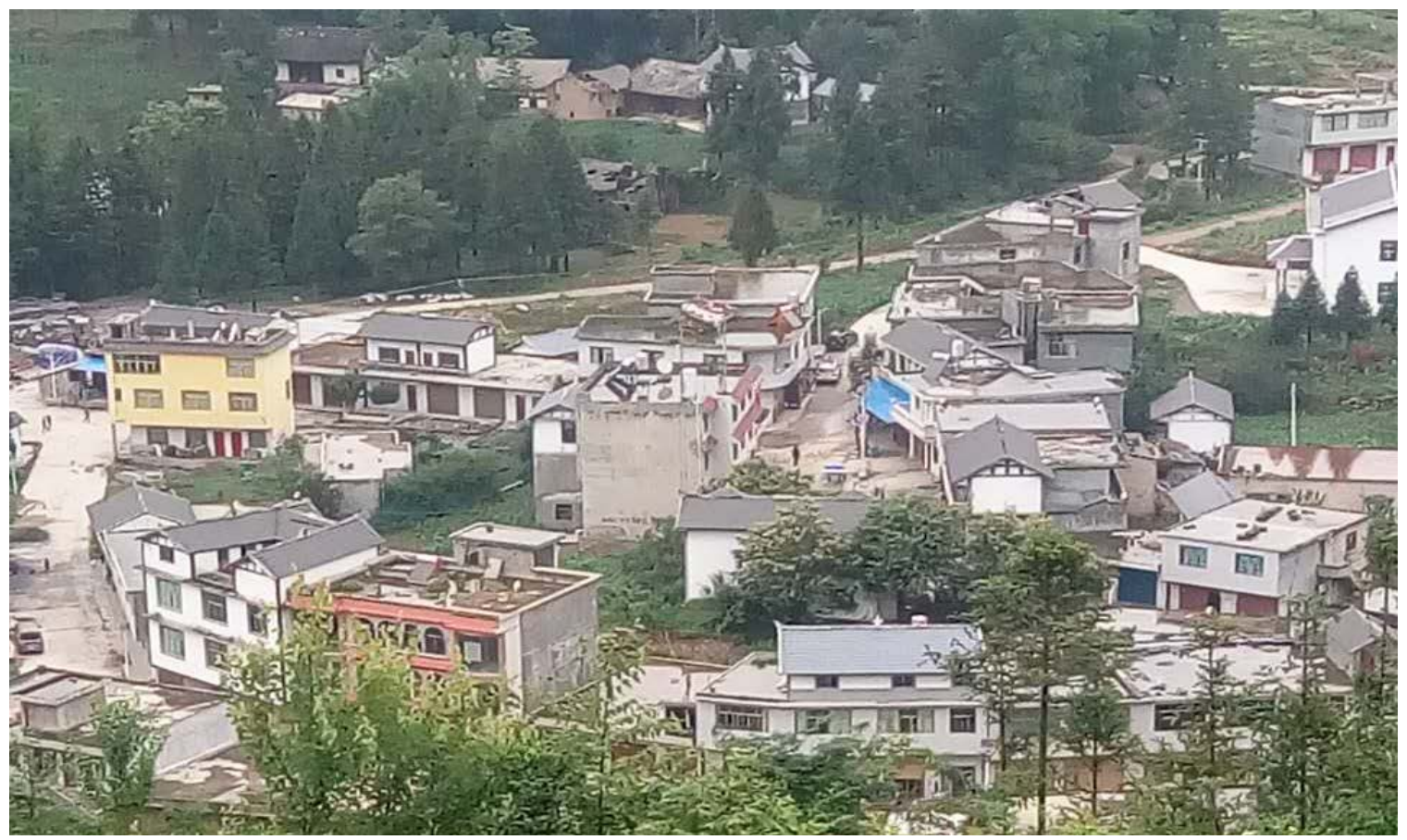

Qianqiu Village in 2017 (photo by Guobao Wu).

The houses at the village entrance have aggregated along the road that was initially improved under the project, which now forms a "street life." The street along the road provided the space for villagers to engage in many activities, including conducting small-scale businesses and tourism.

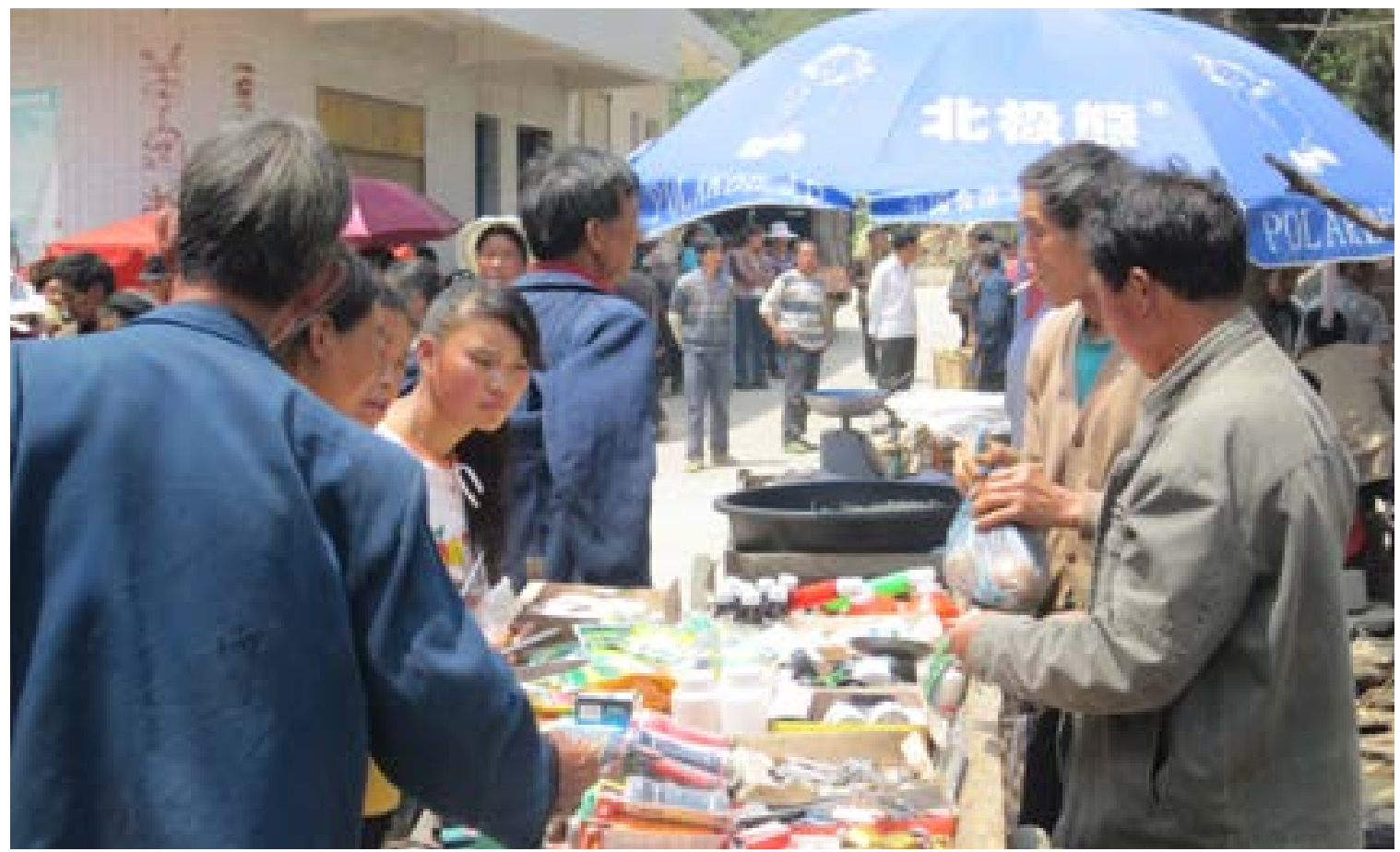

A village market (photo by project team) 
In the entire village, more than 130 households built new houses. Of these, $90 \%$ have two or three floors. The new houses have greatly improved the villagers' housing condition. Before the project, an old wooden house averaged three rooms and a space of 60 square meters. Now, the new brick cement houses are stronger, more spacious, and cleaner. In addition, the value of houses rose steadily.

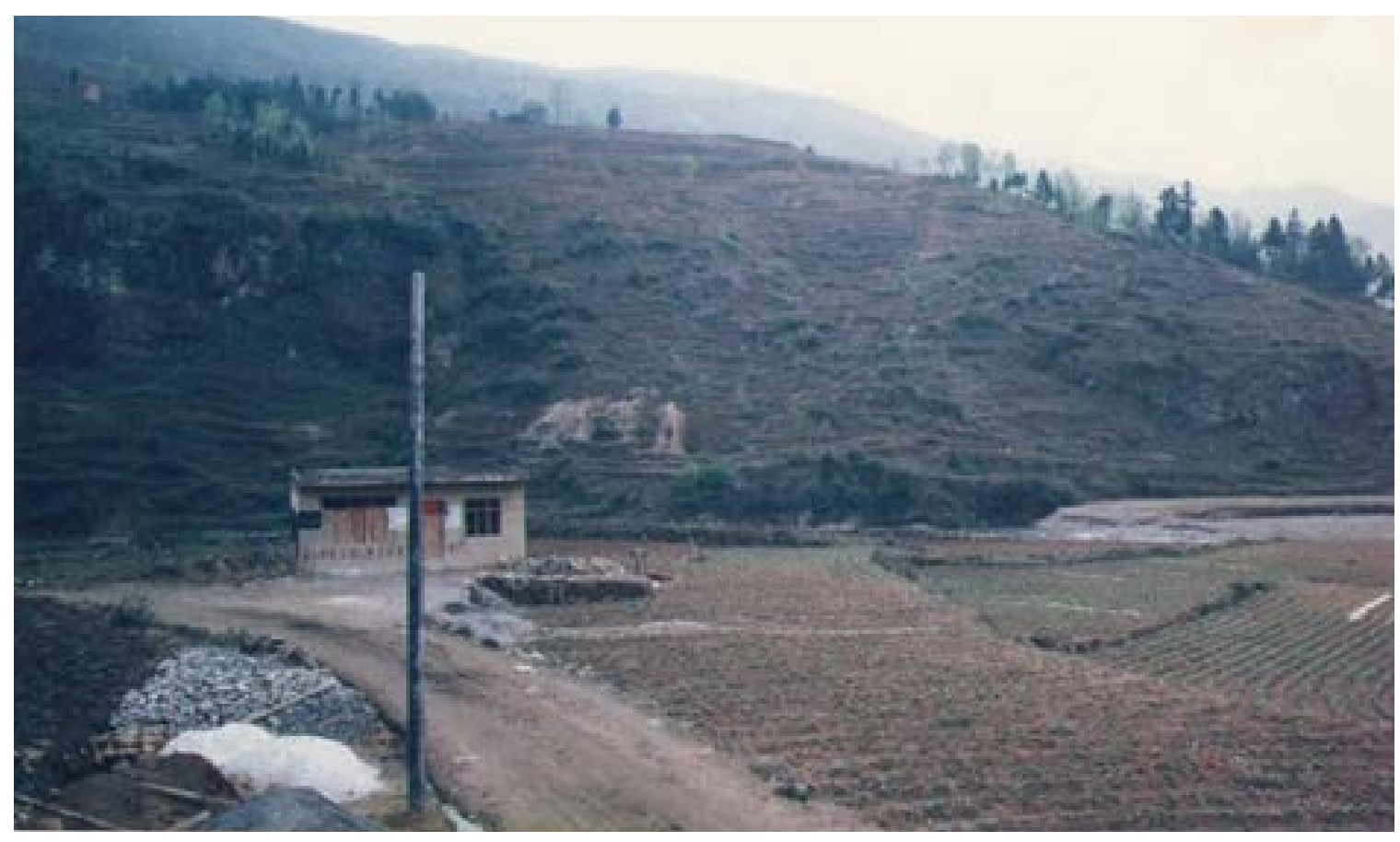

An old house at the village entrance in 2001 (photo by project team).

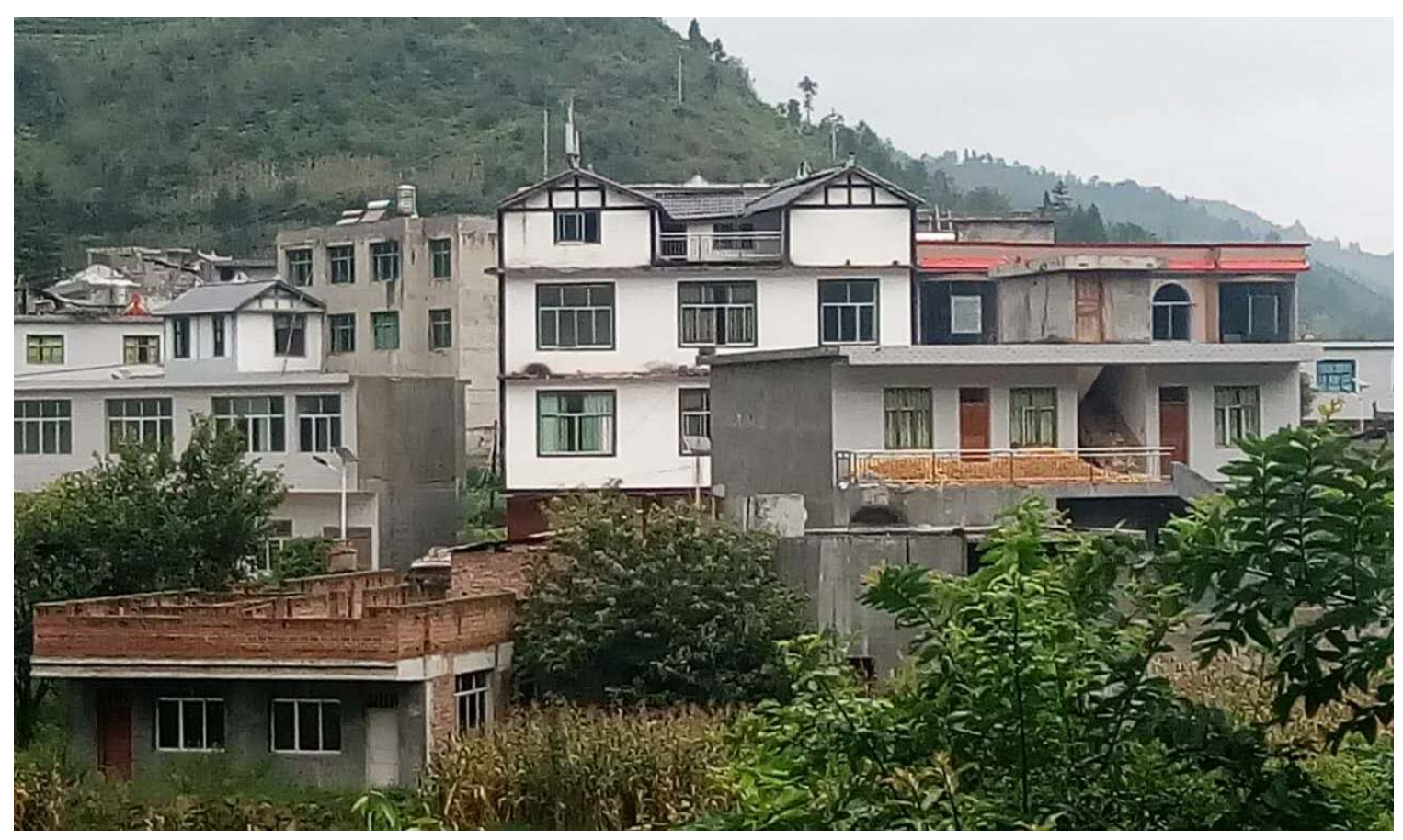

Multistory houses in the village center in 2017 (photo by Guobao Wu). 
The government recently provided additional support for rebuilding farmers' houses with the housing subsidies. This has facilitated further improvement of housing conditions and more concentration of housing along the road and in the village center.

\section{Changes in Livelihood and Income Sources}

The villagers' livelihood has significantly changed in Qianqiu Village. Before the project, almost all households were fully dependent on agriculture for their livelihood. There were less than a dozen households who had their family members working outside the village. Those working outside the village were mainly single males, and very few were women. Most of the young and middle-aged women were engaged in agriculture in the village.

After the pilot project and follow-up activities, the improved infrastructure resulted in labor saving; and it boosted increased exposure and outmigration for outside jobs. Most of the young men and women migrated to urban areas in search of outside jobs, and there are few young residents in the village.

While young men mostly work in cities and come back to the village only during the village's annual festival, young women come back to the village after giving birth, and stay on for 1 year to take care of their babies.

In most cases, both husband and wife migrate to

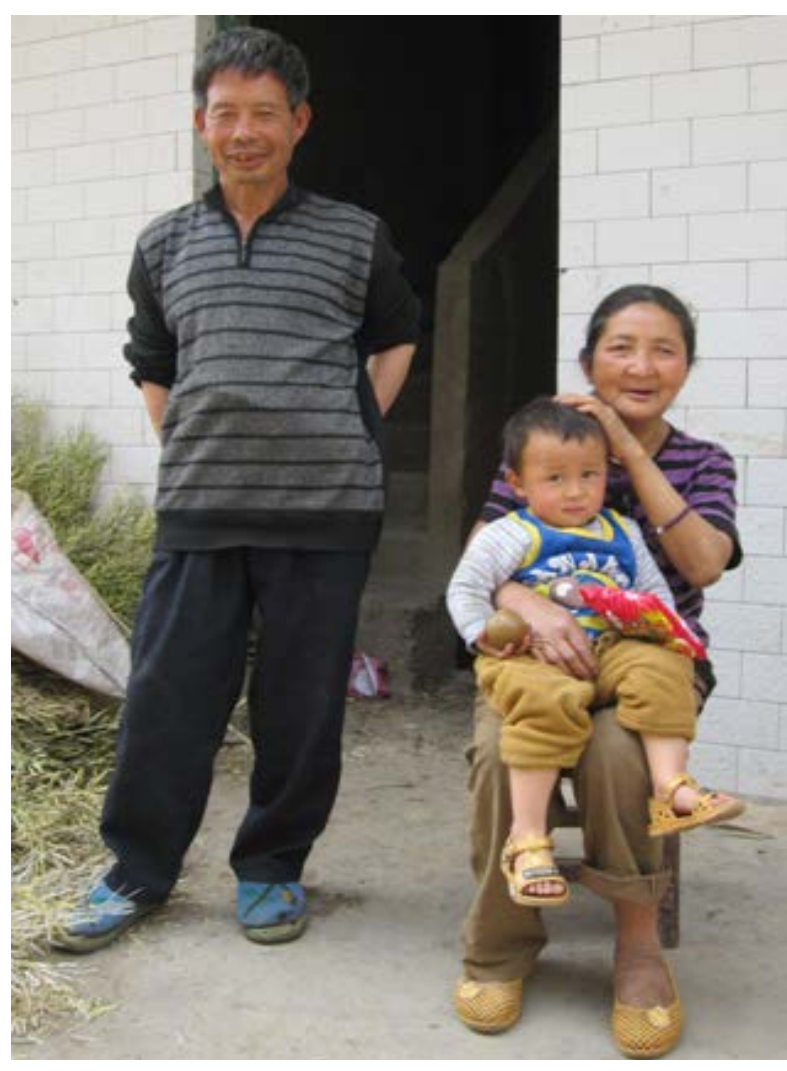

Grandparents taking care of their grandchild (photo by project team).

urban areas to do outside jobs, leaving young children behind to be looked after by their grandparents.

After a decade of the project, most households' income came from non-agricultural employment, mainly remittances from the younger generation working outside. It is estimated that outside employment contributed about $70 \%$ of the total household income, and the agricultural income constituted only $25 \%$. Transfer payments, including subsistence allowance, old age pension, and other support, contributed about $5 \%$.

The farmers' income in Qianqiu Village has kept rising in recent years with the increase of migrated employment and the development of farmers' cooperatives.

\section{Changes in Agricultural Production}

Water, electricity, roads, and other infrastructure contributed to improved agricultural production of the farmers in Qianqiu Village. 
Crop yields improved. Crop yield of potato and corn in dry land increased by 50\%, mainly due to the introduction of new varieties of seeds and the use of more chemical fertilizers by up to four times than before.

More vegetables are now grown, as there is more demand for vegetables within the village as well as outside. In contrast, rice crop yields did not grow as much.

The village witnessed an initial stage of commercialization of family farming. Many households are involved in raising of poultry and pigs, and selling of these into markets. There is increased enthusiasm among farmers for new breeding of animals or expanding the scale of existing breeding.

According to estimates after the project completion, the per capita livestock production rose by $87 \%$, the per capita poultry production rose by $218 \%$, and the per capita chicken egg production increased by $52 \%$. The commercialization trend of breeding industry continues.

However, farmland areas decreased due to drought and unavailability of water for irrigation. Most lands are barren and dry.

Many lands have been converted into orchards or forests since the drought in 2010. New fruit trees have been introduced in these lands. This situation continues due to the dry climate and rocky lands, as well as a shortage of labor.

Some important progress has been made in agricultural production in Qianqiu Village recently. At least two farmers' productive cooperatives have been formed to improve the economic scale of production and better link to the market. Organic fruit, such as waxberry and Chinese dates, have been produced in scale, which helped increase the income of local farmers.

\section{New Enterprises and Businesses}

With the improvement in infrastructure and awareness of villagers, new enterprises and businesses have emerged. Outside employment has given villagers ideas about enterprises such as mills, workshops, and the cultivation of fruit trees. There have been several successful businesses, including a brick factory, a barbecue shop, a corn winery, and fruit trees. These businesses provide more incomegenerating opportunities for the villagers.

There are many good examples of family-run enterprises, including (i) a cement brick factory, (ii) a barbecue business, (iii) a workshop producing corn wine and raising pigs, (iv) a small construction company, ( $v$ ) a waxberry tree plantation, and ( $v i)$ a sow-raising farm. All of these businesses took advantage of the improved infrastructure, notably the paved road and provision of electricity.

Some of the local businesses also generated employment opportunities for villagers. The cement brick factory, for instance, employed 20 workers in addition to members of the family who own the business.

The development of farmers' cooperatives is the new progress made in this regard. 


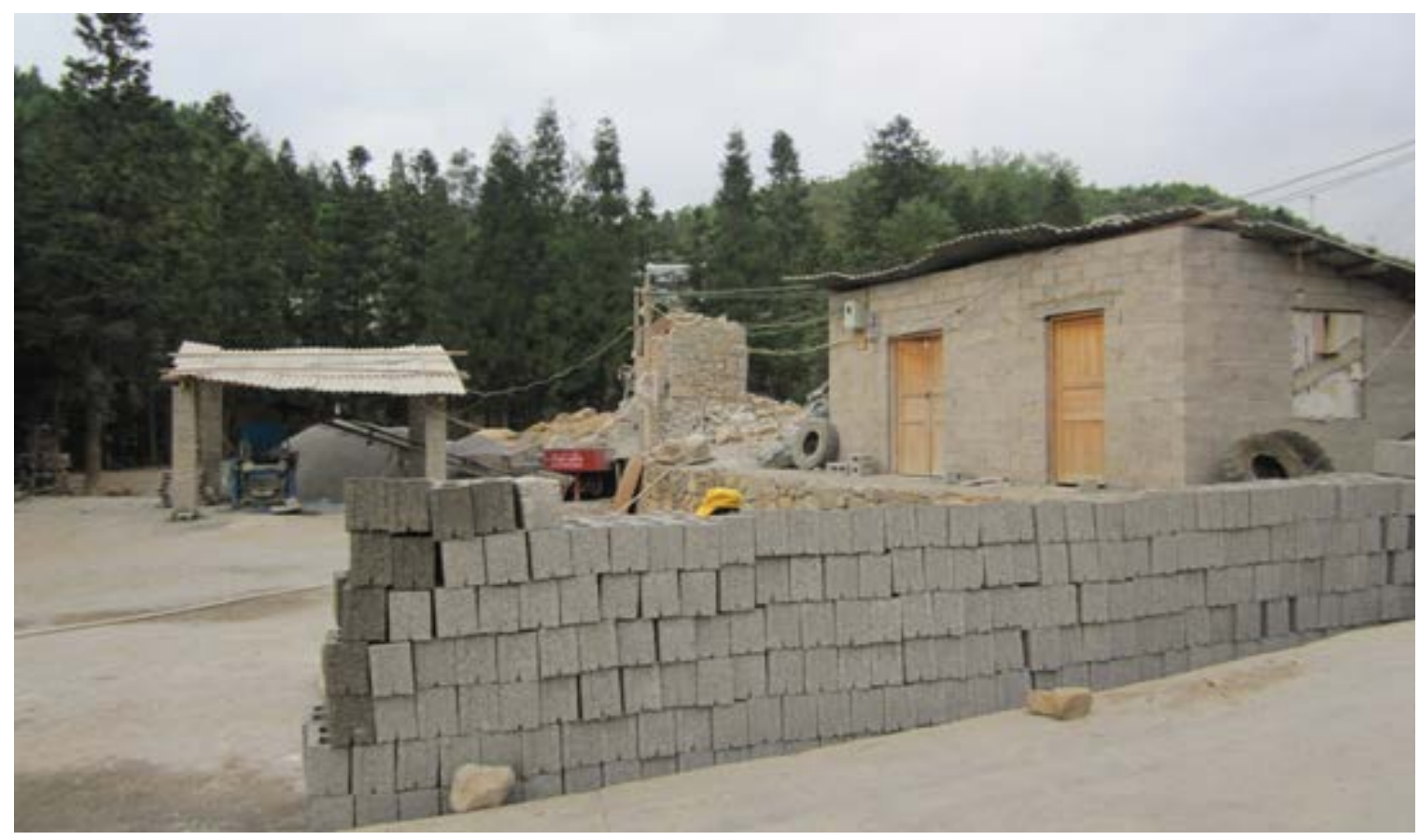

A cement brick factory (photo by project team).

\section{Changes in Villagers' Living Standard and Lifestyle}

The living standards of villagers have improved, which are reflected in improved housing, increased nutrition intake, increased gift giving, and improved education of children.

Most households have two-story houses with cement structures compared with the wooden one-story houses they had before. Households also have bigger and cleaner living spaces.

Food security has improved with a more balanced nutrition for villagers. Before the project, and due to the lack of food, farmers rarely grew vegetables, except some Chinese cabbage at the edge of their farmlands; and their food was mainly corn.

Nowadays, rice supplemented by corn has become the main food source; and farmers eat more vegetables. Farmers can also afford to buy big pigs during the Spring Festival.

The food consumption structure has become closer to that of urban residents. According to estimates, after the decade of the project, Qianqiu Village's per capita food consumption was 234 kilograms (kg), per capita consumption of vegetables was $95 \mathrm{~kg}$, per capita consumption of livestock meat was $33 \mathrm{~kg}$, per capita consumption of poultry was $3 \mathrm{~kg}$, per capita egg consumption was 196 pieces, and per capita consumption of edible vegetable oil was $4 \mathrm{~kg}$.

Household appliance ownership has increased significantly. For example, per household TV sets was 0.34, washing machines was 0.12 , sewing machines was 0.10 , and DVD players was 0.04 after the project completion. These households did not own TV sets, DVD players, and washing machines before the project. 
Gift giving has increased. The previous culture of giving small-scale in-kind gifts has been replaced now with larger and cash gifts. The expenditure on social relationship increased by $67 \%$.

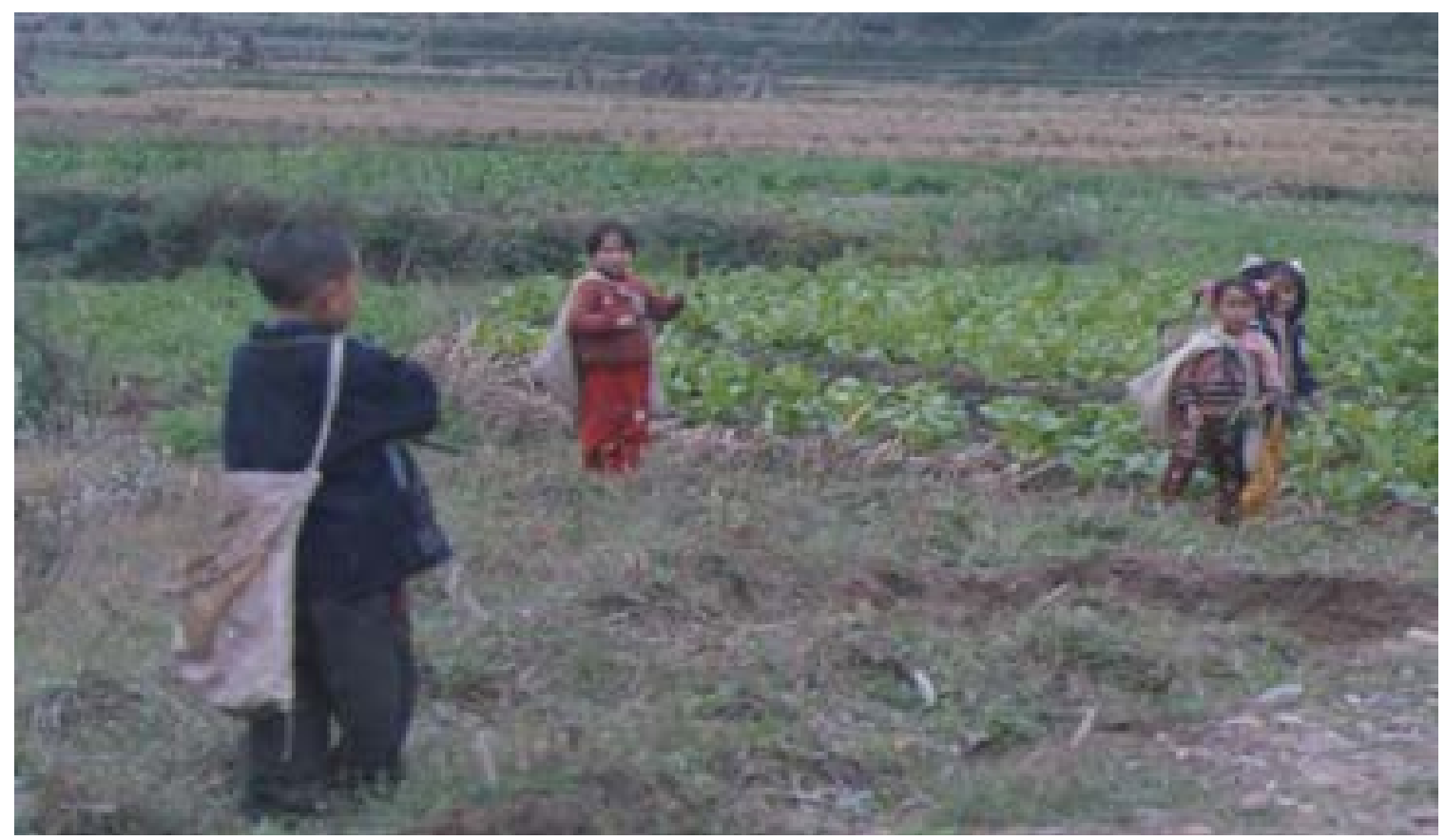

Children in a field after school in 2001 (photo by project team).

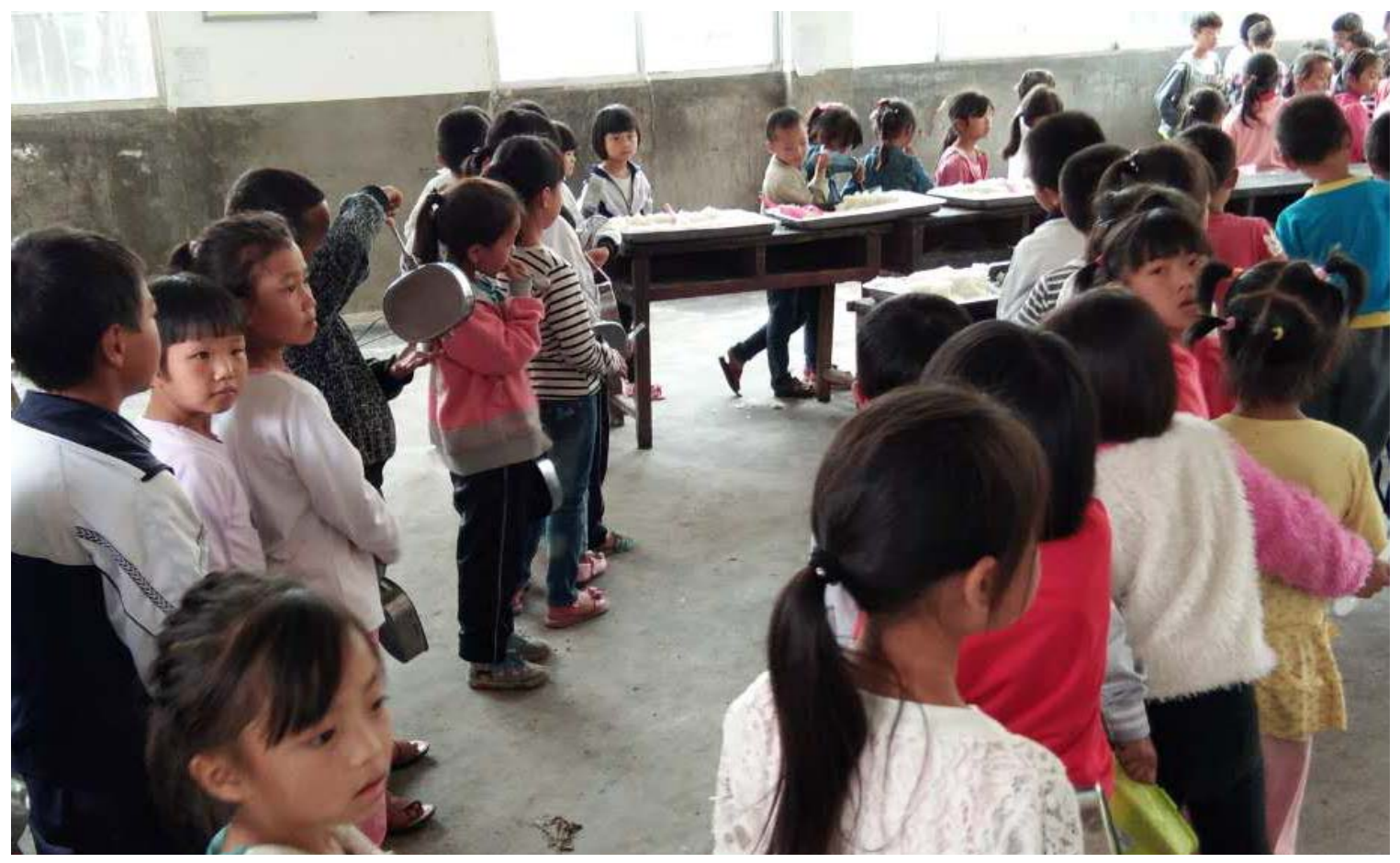

Children in school in 2017 (photo by Guobao Wu). 
Children's education has significantly improved. Parents nowadays give more emphasis on children's education. Many families have migrated to urban centers so that their children could attend better schools.

According to estimates after the project completion, Qianqiu Village's per capita spending on education and culture rose 2.5 times. Villagers' awareness of new information and technology has increased due to contact with outside world through TV sets, mobile telephones, and migration.

As a result of income growth in recent years, more farmers bought cars and made more frequent communication with the Nayong County and the Shuicheng City, a prefecture-level city about 2 hours from the Qianqiu Village.

\section{Poverty Reduction Impacts}

The extent of income poverty has been greatly reduced in the village. According to the national poverty standard, the incidence of income poverty of Qianqiu Village fell from $73.3 \%$ before the project to $11.8 \%$ after the project.

The per capita net income of the farmers in Qianqiu Village increased significantly after the project implementation, from CNY788 before the project to CNY2,045 after the project.

Similar to the net income, the living consumption spending of the farmers in Qianqiu Village increased after the project implementation, from CNY739 before the project to CNY1,278 after the project.

\section{CONCLUSION AND RECOMMENDATIONS}

Poverty reduction is a challenging task. It requires sound national poverty reduction strategies and good local practices. Over the past 3 decades, the People's Republic of China (PRC) has implemented several poverty reduction strategies and has lifted the majority of its population from poverty; although, it still has some pockets of poverty in rural areas, particularly in harsh and remote locations. The PRC's poverty reduction strategies have focused on providing poverty reduction opportunities by building and transferring assets to the poor in rural poverty-stricken areas.

The pilot project's model of poverty reduction through participatory and integrated rural infrastructure and community development proved to be very successful. The pilot project successfully mobilized the local villagers, and developed the essential rural infrastructure comprising water supply, village roads, irrigation and flood control, and electricity. It provided a community development fund and developed the village's capacity as well.

The improved infrastructure and increased capacity greatly benefited the villagers in many ways, including access to safe drinking water supply, irrigation and flood control services, electricity supply for household and livelihood use, and improved road transport and connectivity. The community development fund also enhanced access to microfinance, and capacity building initiatives provided new skills and confidence for the villagers. There were long-term positive changes observed in the pilot village. The farmers have better houses, new sources of income, more household assets (TV sets, and mobile telephones) and reduced income poverty. 
However, the village witnessed a downward trend particularly in terms of farmland and irrigation. Farmland areas and availability of irrigation water decreased since a drought in 2010, although there were initial improvements immediately after the project. This was due to a continuous dry climate and no provision of adequate water resource development and supply of irrigation water. This is a great impediment for sustainable development of farming, food production, and poverty alleviation in the village.

While capacity building, including microfinance and skills training, helped farmers improve farming and animal husbandry, further support is needed. Support needs to be specifically targeted to sustainable farming and revegetation of drylands and karst areas with efficient irrigation technology and management.

The following recommendations are provided based on the Asian Development Bank's pilot project experiences:

(i) Poverty reduction through participatory integrated infrastructure and community development should be further supported and scaled up. This is a successful model for poverty alleviation in rural villages in poor counties like Nayong County.

(ii) More infrastructure support is needed, particularly on water resource development and irrigation systems to provide adequate water for sustainable farming. Addressing water scarcity is particularly important in the karst area where land is mostly dry, steep, and rocky; and is prone to soil degradation due to lack of adequate water. To adapt to the continued dry climate, sources of irrigation water need to be improved.

(iii) Farmers should be supported to develop sustainable farming in low lands, and plantation of fruit and other trees in steep dry lands.

(iv) More capacity building support through excursion tours and skills training (e.g., fruit tree planting) should be provided to farmers so that they can generate more income.

Further infrastructure and community capacity building projects should be provided for the villages in Nayong County and other poor counties for poverty alleviation. This will require additional funding as well as technical support from the government and its development partners. 


\section{REFERENCES}

Asian Development Bank (ADB). 2004. Technical Assistance Completion Report: Study on Ways to Support Rural Poverty Reduction Projects in the People's Republic of China (PRC). Manila. https://www.adb.org/sites/default/files/project-document/69839/tacr-prc-3150.pdf.

ADB. 2007. Technical Assistance to the People's Republic of China for Supporting Strategic Knowledge Products and Research Networking. Manila.

ADB. 2012. Comprehensive Community Development for Poverty Reduction-Case Studies of Community Poverty Reduction in Nayong of Guizhou. Manila.

Center for Integrated Agriculture Development. 2012. Evaluation Report of the Pilot Project of ADB in Nayong, Guizhou Province. China Agricultural University.

H. Gao, W. Wang, and C. Huang. 2001. Study on Poverty Reduction and Development Planning. Beijing: China Financial \& Economic Publishing House.

Government of the PRC, Department of Household Survey, National Bureau of Statistics (NBS). 2016. Poverty Monitoring Report of Rural China 2016. Beijing: China Statistics Press.

Government of the PRC, NBS. 2016. China Statistical Yearbook 2016. Beijing: China Statistics Press.

Government of the PRC, NBS. 2017. Statistical Communique on National Economic and Social Development in 2016. http://www.stats.gov.cn/tjsj/zxfb/201702/t20170228_1467424.html.

Government of the PRC, State Council. 2016. 13th Five-Year Poverty Reduction Plan of the PRC. Beijing. http://www.gov.cn/zhengce/content/2016-12/02/content_5142197.htm.

J. Jalan and M. Ravallion. 1998. Are There Dynamic Gains from a Poor-Area Development Program? Journal of Public Economics. 67. pp. 65-85.

Leading Group for Poverty Reduction and Development (LGPRD). 2001. China's Rural Poverty Reduction and Development Compendium (2001-2010). Beijing.

LGPRD. 1994. The 8-7 Poverty Reduction Plan. Beijing.

A. Park, W. Sangui, and G. Wu. 2002. Regional Poverty Targeting in China. Journal of Public Economics. 86. pp. 123-153.

W. Sangui. 1994. Poverty Problems and Economic Development. Beijing: Rural Reading Materials Press.

W. Sangui, L. Wen, and L. Yun. 2004. Allocation of the Poverty Reduction Funds in China: Sectoral Distribution and its Impacts. Journal of Agrotechnical Economics. 5. pp. 45-49.

World Bank. 2001. China: Overcoming Rural Poverty. Washington, DC. 


\section{Poverty Reduction and Development}

National Strategies and a Case Study of ADB-Funded Pilot Project in Nayong County in Guizhou Province, People's Republic of China

Poverty reduction is a challenging task. It requires sound national poverty reduction strategies and good local practices. Over the past 3 decades the People's Republic of China (PRC) has implemented several poverty reduction programs and has lifted the majority of its population from poverty. This paper provides an overview of the PRC's national poverty reduction strategies and highlights a case study of a pilot project in Nayong County of Guizhou Province that was funded by the Asian Development Bank. It shows how national poverty reduction strategies and local-level projects can contribute successfully to poverty reduction and development.

\section{About the Asian Development Bank}

ADB's vision is an Asia and Pacific region free of poverty. Its mission is to help its developing member countries reduce poverty and improve the quality of life of their people. Despite the region's many successes, it remains home to a large share of the world's poor. ADB is committed to reducing poverty through inclusive economic growth, environmentally sustainable growth, and regional integration.

Based in Manila, ADB is owned by 67 members, including 48 from the region. Its main instruments for helping its developing member countries are policy dialogue, loans, equity investments, guarantees, grants, and technical assistance. 